\title{
CAUSES OF THE KOREAN FINANCIAL CRISIS: LESSONS FOR POLICY
}

\author{
Joon-Ho Hahm \\ Frederic S. Mishkin \\ Working Paper 7483 \\ http://www.nber.org/papers/w7483
}

\author{
NATIONAL BUREAU OF ECONOMIC RESEARCH \\ 1050 Massachusetts Avenue \\ Cambridge, MA 02138 \\ January 2000
}

This paper is a part of the research program supported by the Korea Foundation, and prepared for presentation at the KDI international conference, "The Korean Crisis: Before and After," held in Seoul, Korea on October 15, 1999. The authors are grateful to Hong-Kyu Park for his excellent research assistance and to Charles Himmelberg and the participants at the Finance lunch seminar at the Graduate School of Business, Columbia University for their helpful comments. Any opinions expressed in this paper are those of the authors and not those of the Korea Development Institute, Columbia University, or the National Bureau of Economic Research.

(C) 2000 by Joon-Ho Hahm and Frederic S. Mishkin. All rights reserved. Short sections of text, not to exceed two paragraphs, may be quoted without explicit permission provided that full credit, including $\mathbb{C}$ notice, is given to the source. 
Causes of the Korean Financial Crisis: Lessons for Policy Joon-Ho Hahm and Frederic S. Mishkin

NBER Working Paper No. 7483

January 2000

JEL No. F3, E5, G2

\section{ABSTRACT}

This paper uses an asymmetric information framework to understand the causes of the recent financial crisis in Korea. It shows that the Korean data is consistent with this explanation of the crisis. It then draws on this analysis to discuss several lessons that can help guide Korean policymakers in the future.

Joon-Ho Hahm

Money and Finance Division

Korea Development Institute

P.O. Box 113, Cheong-Ryang

Seoul 130-012, Korea

jhahm@kdiux.kdi.re.kr
Frederic S. Mishkin

Graduate School of Business

Uris Hall 619

Columbia University

New York, NY 10027

and NBER

fsm3@columbia.edu 


\section{INTRODUCTION}

The financial crisis that hit Korea in the last half of 1997 had a devastating impact on the Korean economy, causing Korea's worst recession in the postwar era. Real GDP growth fell from levels which had been running in the positive 5 to $10 \%$ range before the crisis to a negative $5.8 \%$ rate in 1998. In the aftermath of the crisis, unemployment rose from pre-crisis levels of $2 \%$ to $6.8 \%$ in 1998 and 8.1\% in March 1999.

Why did this crisis happen and what lessons does it hold for how the Korean economy could be better managed in the future?

This paper answers these questions by using an asymmetric information framework to understand the causes and propagation mechanisms of the financial crisis in Korea. It shows that the Korean data is consistent with this explanation of the crisis. The final section of the paper then uses the asymmetric information analysis of the Korean financial crisis to outline several lessons that can guide Korean policymakers in the future.

\section{A GENERIC, ASYMMETRIC INFORMATION ANALYSIS OF FINANCIAL CRISES}

The financial system plays a critical role in the economy because, when it operates properly, it channels funds from those who have saved surplus funds to those who need these funds to engage in productive investment opportunities. The major barrier to the financial system performing this job properly is asymmetric information, the fact that one party to a financial contract does not have the same information as the other party, which results in moral hazard and adverse selection problems. An asymmetric information view of financial crises, described in more detail elsewhere in Mishkin (1996a, 1997a), defines a financial crisis to be a nonlinear disruption to financial markets in which the asymmetric information problems of adverse selection and moral hazard become much worse, so that financial markets are no longer able to efficiently channel funds to those who have the most productive investment opportunities. 


\section{The Causes of Financial Crises}

Financial intermediaries, and particularly banks, have a very important role in financial markets since they are well suited to engage in information-producing activities that facilitate productive investment for the economy. Thus, a decline in the ability of these institutions to engage in financial intermediation and to make loans will lead directly to a decline in investment and aggregate economic activity. When shocks to the financial system make adverse selection and moral hazard problems worse, then lending tends to dry up - even for many of those with productive investment opportunities, since it has become harder to distinguish them from potential borrowers who do not have good opportunities. The lack of credit leads individuals and firms to cut their spending, resulting in a contraction of economic activity that can be quite severe. Four factors can lead to increases in asymmetric information problems and thus to financial instability: deterioration of financial sector balance sheets, increases in interest rates, increases in uncertainty, and deterioration of nonfinancial sector balance sheets due to changes in asset prices. We will discuss each in turn.

\section{Deterioration in Financial Sector Balance Sheets}

If banks (and other financial intermediaries making loans) suffer a deterioration in their balance sheets, and so have a substantial contraction in their capital, they have two choices: either they can cut back on their lending; or they can try to raise new capital. However, when banks experience a deterioration in their balance sheets, it is very hard for them to raise new capital at a reasonable cost. Thus, the typical response of banks with weakened balance sheets is a contraction in their lending, which slows economic activity. Recent research suggests that weak balance sheets led to a capital crunch which hindered growth in the U.S. economy during the early 1990s. ${ }^{1}$

If the deterioration in bank balance sheets is severe enough, it can even lead to bank panics, in which there are multiple, simultaneous failures of banking institutions. Indeed, in the absence of a government safety net, there is some risk that contagion can spread from one bank failure to

\footnotetext{
${ }^{1}$ For example, see Bernanke and Lown (1991), Berger and Udell (1994), Hancock, Laing and Wilcox (1995) and Peek and Rosengren (1995) and the symposium published in the Federal Reserve Bank of New York Quarterly Review in the spring of 1993, Federal Reserve Bank of New York (1993).
} 
another, causing even healthy banks to fail. The source of the contagion is again asymmetric information. In a panic, depositors, fearing the safety of their deposits and not knowing the quality of the banks' loan portfolios, withdraw their deposits from the banking system, causing a contraction in loans and a multiple contraction in deposits, which then causes other banks to fail. In turn, the failure of a bank means the loss of the information relationships in which that bank participated, and thus a direct loss in the amount of financial intermediation that can be done by the banking sector. The outcome is an even sharper decline in lending to facilitate productive investments, with an additional resulting contraction in economic activity.

\section{Increases in Interest Rates}

Asymmetric information and the resulting adverse selection problem can lead to "credit rationing," in which some borrowers are denied loans even when they are willing to pay a higher interest rate. ${ }^{2}$ This occurs because as interest rates rise, prudent borrowers are more likely to decide that it would be unwise to borrow, while borrowers with the riskiest investment projects are often those who are willing to pay the highest interest rates, since if the high-risk investment succeeds, they will be the main beneficiaries. In this setting, a higher interest rate leads to even greater adverse selection; that is, the higher interest rate increases the likelihood that the lender is lending to a bad credit risk. Thus, higher interest rates can be one factor that helps precipitate financial instability, because lenders recognize that higher interest rates mean a dilution in the quality of potential borrowers, and are likely to react by taking a step back from their business of financial intermediation and limiting the number of loans they make.

Increases in interest rates can also have a negative effect on bank balance sheets. The traditional banking business involves "borrowing short and lending long;" that is, taking deposits which can be withdrawn on demand (or certificates of deposit that can be withdrawn in a matter of months) and making loans that will be repaid over periods of years or sometimes even decades. In short, the assets of a bank typically have longer duration assets than its liabilities. Thus, a rise in interest rates directly causes a decline in banks' net worth, because in present value terms, the interest-rate rise lowers the value of assets with their longer duration more than it raises the value of

\footnotetext{
${ }^{2}$ See among others, Stiglitz and Weiss (1981).
} 
liabilities with their shorter duration.

\section{Increases in Uncertainty}

A dramatic increase in uncertainty in financial markets makes it harder for lenders to screen out good from bad credit risks. The lessened ability of lenders to solve adverse selection and moral hazard problems renders them less willing to lend, leading to a decline in lending, investment, and aggregate activity. This increase in uncertainty can stem from a failure of a prominent financial or nonfinancial institution, or from a recession, or from uncertainty about the future direction of government policies.

\section{Deterioration of Nonfinancial Balance Sheets}

The state of the balance sheet of nonfinancial firms is a critical factor for the severity of asymmetric information problems in the financial system. If there is a widespread deterioration of balance sheets among borrowers, it worsens both adverse selection and moral hazard problems in financial markets, thus promoting financial instability. This problem can arise in a variety of ways.

For example, lenders often use collateral as an important way of addressing asymmetric information problems. Collateral reduces the consequences of adverse selection or moral hazard because it reduces the lender's losses in the case of a default. If a borrower defaults on a loan, the lender can sell the collateral to make up for at least some of the losses on the loan. But if asset prices in an economy fall, and the value of collateral falls as well, then the problems of asymmetric information suddenly rear their heads.

Net worth can perform a similar role to collateral. If a firm has high net worth, then even if it defaults on its debt payments, the lender can take title to the firm's net worth, sell it off, and use the proceeds to recoup some of the losses from the loan. High net worth also directly decreases the incentives for borrowers to commit moral hazard because borrowers now have more at stake, and thus more to lose, if they default on their loans. The importance of net worth explains why stock

market crashes can cause financial instability. A sharp decline in the stock market reduces the market valuation of a firms' net worth, and thus can increase adverse selection and moral hazard 
problems in financial markets. ${ }^{3}$ Since the stock market decline which reduces net worth increases incentives for borrowers to engage in moral hazard, and since lenders are now less protected against the consequences of adverse selection because the value of net assets is worth less, lending decreases and economic activity declines.

Increases in interest rates not only have a direct effect on increasing adverse selection problems, as described a moment ago, but they may also promote financial instability through both firms' and households' balance sheets. A rise in interest rates will increase households' and firms' interest payments, decrease cash flow and thus cause a deterioration in their balance sheets, as pointed out in Bernanke and Gertler's (1995) excellent survey of the credit view of monetary transmission. As a result, adverse selection and moral hazard problems become more severe for potential lenders to these firms and households, leading to a decline in lending and economic activity. There is thus an additional reason why sharp increases in interest rates can be an important factor leading to financial instability.

Unexpected changes in the rate of inflation can also affect balance sheets of borrowers. In economies in which inflation has been moderate for a long period of time, debt contracts with long duration have interest payments fixed in nominal terms for a substantial period of time. When inflation turns out to be less than anticipated, which can occur either because of an unanticipated disinflation as occurred in the United States in the early 1980s or by an outright deflation as has occurred in Japan more recently, the value of firms' liabilities in real terms rises, and its net worth in real terms declines. The reduction in net worth then increases the adverse selection and moral hazard problems facing lenders, and reduces investment and economic activity.

In emerging market economies, a decline in unanticipated inflation does not have the unfavorable direct effect on firms' balance sheets that it has in industrialized countries. Debt contracts are of very short duration in many emerging market countries, and since the terms of debt contracts are continually repriced to reflect expectations of inflation, unexpected inflation has little real effect. Thus, one mechanism that has played a role in industrialized countries to promote financial instability has no role in many emerging market countries.

\footnotetext{
${ }^{3}$ See for example, Greenwald and Stiglitz (1988), Bernanke and Gertler (1989), and Calomiris and Hubbard (1990).
} 
On the other hand, emerging market economies face at least one factor affecting balance sheets that can be extremely important in precipitating financial instability that is not important in most industrialized countries: unanticipated exchange rate depreciation or devaluation. Because of uncertainty about the future value of the domestic currency, many nonfinancial firms, banks and governments in emerging market countries find it much easier to issue debt if the debt is denominated in foreign currencies. With debt contracts denominated in foreign currency, when there is an unanticipated depreciation or devaluation of the domestic currency, the debt burden of domestic firms increases. Since assets are typically denominated in domestic currency and so do not increase in value, there is a resulting decline in net worth. This deterioration in balance sheets then increases adverse selection and moral hazard problems, which leads to financial instability and a sharp decline in investment and economic activity.

\section{The Propagation of Financial Crises}

Now that we understand the factors that cause financial crises, we can look at how financial crises propagate. As our discussion above indicates, initially macroeconomic fundamentals are not an important part of the story of why financial crises occur. Instead, what is happening in domestic financial sector is a better place to start.

\section{The First Stage: The Runup to the Currency Crisis}

The first stage leading up to the financial crisis has typically been a financial liberalization, which involved lifting restrictions on both interest-rate ceilings and the type of lending allowed. As a result, lending increased dramatically, fed by inflows of international capital.

Excessive risk-taking is the result for two reasons. First, banks and other financial institutions lack the well-trained loan officers, risk-assessment systems, and other management expertise to evaluate and respond to risk appropriately. This problem is made even more severe by the rapid credit growth in a lending boom which stretches the resources of the bank supervisors. They fail to screen and monitor these new loans appropriately. Second, emerging market countries have been notorious for weak financial regulation and supervision. When financial liberalization

yields new opportunities to take on risk, these weak regulatory/supervisory systems cannot limit the 
moral hazard created by the government safety net, and excessive risk-taking is one result. Even as governments fail in supervising banks, they in effect offer an implicit safety net that banks would not be allowed to go broke, and thus reassure depositors and foreign lenders that they do not need to monitor these banks, since there are likely to be government bailouts to protect them.

A dangerous dynamic emerges. Once financial liberalization is adopted, foreign capital flows into banks in these emerging market countries because they pay high yields in order to attract funds to rapidly increase their lending, and because such investments are viewed as likely to be protected by a government safety net, either from the government of the emerging market country or from international agencies such as the IMF. The capital inflow problem is further aggravated by government policies of keeping exchange rates pegged to the dollar, which probably gives foreign investors a sense of lower risk. The capital inflows fuel a lending boom which leads to excessive risk-taking on the part of banks, which in turn leads to huge loan losses and a subsequent deterioration of banks' and other financial institutions' balance sheets.

This deterioration in bank balance sheets, by itself, might be sufficient to drive these countries into a financial and economic crisis. As explained earlier, a deterioration in the balance sheets of banking firms can lead them at a minimum to restrict their lending, or can even lead to a full-scale banking crisis which forces many banks into insolvency, thereby nearly removing the ability of the banking sector to make loans. The resulting credit crunch can stagger an economy.

Stock market declines and increases in uncertainty are additional factors that can precipitate full-blown crises. Increases in uncertainty, either because of the failure of major financial or nonfinancial firms, or because of political uncertainty can lead to substantial declines in securities markets. As we have seen, an increase in uncertainty and a decrease in net worth as a result of a stock market decline increase asymmetric information problems. It becomes harder to screen out good from bad borrowers, and the decline in net worth decreases the value of firms' collateral and increases their incentives to make risky investments because there is less equity to lose if the investments are unsuccessful. The increase in uncertainty and stock market declines that occur before the crisis, along with the deterioration in banks' balance sheets, worsen adverse selection and moral hazard problems and make the economies ripe for a serious financial crisis. 


\section{The Second Stage: From Currency Crisis to Financial Crisis}

The deterioration in bank balance sheets in the first stage of the crisis is a key factor leading to the second stage, a currency crisis. With a weakened banking sector it becomes very difficult for the central bank to defend its currency against a speculative attack. Any rise in interest rates to keep the domestic currency from depreciating has the additional effect of weakening the banking system further because the rise in interest rates hurts banks' balance sheets. This negative effect of a rise in interest rates on banks' balance sheets occurs because of their maturity mismatch and their exposure to increased credit risk when the economy deteriorates. Thus, when a speculative attack on the currency occurs in an emerging market country, if the central bank raises interest rates sufficiently to defend the currency, the banking system may collapse. Once investors recognize that a country's weak banking system makes it less likely that the central bank will take the steps to successfully defend the domestic currency, they have even greater incentives to attack the currency because expected profits from selling the currency have now risen. Thus, with a weakened banking sector, a successful speculative attack is likely to materialize.

Once a full-blown speculative attack occurs and causes a currency depreciation, the institutional structure of debt markets in emerging market countries now interacts with the currency devaluations to propel the economies into full-fledged financial crises. Because so many firms in these countries have debt denominated in foreign currencies, depreciation of their currencies results in increases in their indebtedness in domestic currency terms, even though the value of their assets remains unchanged. As a result firms' balance sheets take a big negative hit, which causes a dramatic increase in adverse selection and moral hazard problems.

The collapse of currencies can also lead to a rise in actual and expected inflation in these countries, leading to sky high interest rates. The resulting increase in interest payments causes reductions in households' and firms' cash flow, which leads to further deterioration in their balance sheets. A feature of debt markets in emerging-market countries is that debt contracts have very short durations, typically less than one month. Thus the rise in short-term interest rates in these countries means that the effect on cash flow and hence on balance sheets can be substantial. As our asymmetric information analysis suggests, this deterioration in households' and firms' balance sheets increases adverse selection and moral hazard problems in the credit markets, making lenders 
even less willing to lend.

Further deterioration in the economy would occur because the collapse in economic activity and the deterioration in the cash flow and balance sheets of both firms and households would lead to a worsening banking crisis. The deterioration in the economy and firms and households' balance sheets would lead to many of them to no longer be able to pay off their debts, resulting in substantial losses for the banks. Even more problematic for the banks in emerging market countries is that they have many short-term liabilities denominated in foreign currencies, and the sharp increase in the value of these liabilities after a devaluation leads to a further deterioration in the banks' balance sheets. ${ }^{4}$ As we have seen, a banking crisis of this type hinders the ability of the banks to lend and also makes adverse selection and moral hazard problems worse in financial markets because banks are less capable of playing their traditional financial intermediation role.

The result of a currency crisis, which causes a sharp deterioration in both financial and nonfinancial firm balance sheets, is a contraction in lending and a severe economic downturn. Financial markets are then no longer able to channel funds to those with productive investment opportunities, which has devastating effects on the economy.

\section{HOW DOES THE ASYMMETRIC INFORMATION ANALYSIS FIT THE FACTS IN THE KOREAN CRISIS}

Now that we have an outline of an asymmetric information analysis of financial crises, we can see whether the events and data for Korea provide support for this view. We first outline the

\footnotetext{
${ }^{4}$ An important point is that even if banks have a matched portfolio of foreign-currency denominated assets and liabilities and so appear to have hedged foreign-exchange market risk, a devaluation can nonetheless cause substantial harm to bank balance sheets. The damage occurs because the mismatch between foreign-currency denominated assets and liabilities on borrowers' balance sheets can lead to defaults on their loans, thereby converting a market risk for borrowers to a credit risk for the banks that have made the foreign-currency denominated loans.
} 
facts on macroeconomic and balance-sheet fundamentals, then examine what factors caused balance sheets to deteriorate in Korea, and then look at the sequence of events as the crisis unfolded.

\section{Macroeconomic Fundamentals}

At the onset of the crisis, the basic macroeconomic fundamentals in Korea appeared to be strong (See Table 1). In 1996 and 1997, the government budget was close to being in balance and the current account deficit was falling from $4.4 \%$ to less than $2 \%$ of GDP. Inflation remained below $5 \%$, and the economy was expected to grow more than $6 \%$ in real terms. The gross savings ratio also remained high, exceeding 30\%. Korea also had not been experiencing a substantial real appreciation as can be seen in the real effective exchange rates. In the three years prior to the crisis, the real exchange rate for Korea was essentially flat. From a macroeconomic point of view, Korea looked like a well managed economy and this is a key reason why the financial crisis in Korea was such a surprise to the markets.

The data in Table 1 strongly suggests that the financial crisis cannot be attributed to macroeconomic fundamentals. Indeed, similar conclusions generally apply to other emerging market countries that have recently experienced crises such as Mexico and the other East Asia crisis countries, Thailand, Malaysia, Indonesia and the Philippines. ${ }^{5}$ Indeed these findings are consistent with the asymmetric information analysis of financial crises outlined above, which does not stress macroeconomic fundamentals as the key trigger to financial crises.

\section{Balance-Sheet Fundamentals: Overall Economy}

Despite the strong macroeconomic fundamentals, as the asymmetric information analysis indicates, Korea was vulnerable to a financial crisis because of weak balance-sheet fundamentals for the overall economy. Table 2 provides data on some measures of Korea's external liabilities.

\footnotetext{
${ }^{5}$ For example, see Corsetti, Pesenti, Roubini (1998), and Mishkin (2000).
} 
Gross external liabilities had been growing at rates exceeding 30\% from 1994 to 1996, a period of comprehensive capital account liberalization. The amount of external liabilities relative to GDP was also rising rapidly over the same period, rising from the $20 \%$ level prior to 1994 to above $30 \%$ by 1996 and 1997. A rapid increase in private sector borrowings - both direct borrowings of the corporate sector and bank borrowings to finance investments of the corporate sector - accounted for most of the increase in external debt.

While the external liability to GDP ratio reached a level around $33 \%$ in 1997 , the level itself was probably not an unsustainable one given Korea's economic growth potential. ${ }^{6}$ The problem instead lay in the relatively high portion of short-term external debt, and the termmismatch, which was a possible signal of serious external liquidity problems. ${ }^{7}$ Indeed, throughout the 1990s, the share of short-term liabilities out of total external liabilities remained at a level of more than $50 \%$, while the foreign exchange reserve position was not sufficient to cover the short-term external liabilities. As can be seen in Table 2, by 1996 the ratio of shortterm external liabilities to official foreign exchange reserves had risen to nearly $280 \%$. Relatively sound macroeconomic indicators such as stable GDP growth, budget balance, high saving rates, low inflation, were disguising structural vulnerability in terms of high foreign exchange liquidity risks.

\section{Balance-Sheet Fundamentals: The Financial Sector}

As our discussion of the asymmetric information view of financial crises indicates, the deterioration of balance sheets in the financial sector is likely to be an important factor causing financial crises. In this section, we try to uncover the true status of bank balance sheets at the onset of the crisis to see if they played the role in the Korean crisis suggested by the asymmetric information story.

Note that prior to the crisis, the loan classification criteria and loan loss provision

\footnotetext{
${ }^{6}$ Cohen(1992) and Milesi-Ferretti and Razin (1996), among others, provide an interesting overview for the debt sustainability issues of the developing countries.

${ }^{7}$ By now, a comprehensive volume of literature has emerged on the early warning models of financial crisis. See, Frankel and Rose (1996) and Goldstein (1996), among others.
} 
requirements in Korea had been very lenient compared to international standards. Related regulations had been gradually upgraded making the consistent tracing of bank balance sheets extremely difficult. Thus, it is necessary to adjust the bank balance sheets by applying consistent criteria in order to uncover the true situation.

Table 3 shows three officially released indicators of bank balance sheets - the bank capital to total asset ratio, the BIS risk adjusted capital ratio and the non-performing loan (NPL) ratio. ${ }^{8}$ Both the bank capital to total asset ratio and the BIS capital ratio reveal a declining trend up to 1997 indicating that indeed there was a deterioration in bank balance sheets before the crisis. However, despite the decreasing trend, bank capital adequacy had not been severely eroded before the crisis as the capital to total asset ratio was still above $4 \%$ and the BIS ratio above $8 \%$ in $1996 .{ }^{9}$ Only in the year of crisis, did it fell sharply below the minimum $8 \%$ BIS and $4 \%$ capital to asset ratio. The nonperforming loan ratio displays quite a different trend. The NPL ratio had been decreasing before 1997 indicating that the asset quality was actually improving up to 1996 . Hence, when we rely on the official data, it is difficult to conclude that there had been a substantial deterioration in bank balance sheets prior to the financial crisis.

Other indicators of bank performance, such as those in Table 4, suggest that the conclusion from official data that banks were not experiencing difficulties is highly suspect. As can be seen, during the 1994-97 period, both the return on assets (ROA) and return on equity (ROE) of domestic commercial banks had been decreasing, indicating that the profitability of banking sector had been shrinking at the onset of the crisis. Operating income per employee shows a similar trend although it increased slightly in 1996.

Two additional interesting points emerge from Table 4. First, the performance of domestically operating foreign banks was not weak during the same period. Contrary to domestic commercial banks, both the ROA, ROE and operating income per employee of foreign bank branches were improving during the $1995-97$ period. Also note that the interest rate spread

\footnotetext{
${ }^{8}$ In computing the BIS ratio, tier II capital such as subordinated debt and allowances for loan loss is counted as capital, while it is not counted as bank capital in the normal capital to total asset ratio. Hence, the capital to total asset ratio is usually less than the BIS ratio.

${ }^{9}$ For example, according to the U.S. prudential regulations, banks with BIS ratio higher than $8 \%$ and capital to total asset ratio higher than $4 \%$ are classified as 'adequately capitalized'.
} 
between bank loans and deposits, an indicator of bank operating profitability, had been continuously widening since 1993. Based on these observations, it seems more likely that the weakening bank performance was driven more by the deterioration in asset quality rather than the competition from non-bank financial institutions.

Now we turn to investigating more direct evidence on the degree of deterioration in bank balance sheets. Without detailed data on individual bank portfolios, it is impossible to reconstruct risk adjusted BIS ratios, and hence, we focus on the bank capital to total assets ratio. Note that, during the 1990s, banks were allowed to provision less than $100 \%$ of required allowances for loan losses, and the regulatory standard was gradually strengthened to rise to $100 \%$ in $1998 .{ }^{10}$ Hence, adjusting for insufficient loan loss allowances is the first step in obtaining estimates of the true status of bank capital adequacy. ${ }^{11}$

Table 5 shows the adjustment to bank capital that allows for insufficient provision for expected loan losses in the 1992-97 years. The first row of the table shows unadjusted capital in the bank balance sheets, the second row the actual amount of loan loss allowances accumulated, and the third row the ratio of actual to required loan loss allowances at the end of each year. The fourth row indicates how much more the loan loss allowances would have been provisioned if the ratio had been set at $100 \%$ as it was from 1998 on. Subtracting this number from the first row with unadjusted bank capital, yields the final row which provides the adjusted bank capital amount with $100 \%$ loan loss provisioning.

Note that Table 5 does not account for changes in asset classification standards, which were strengthened in 1994 and 1998. From 1994, banks were required to classify their assets into five

\footnotetext{
${ }^{10}$ From 1994, banks were required to classify their assets into five categories according to borrower's overdue status and debt service capability. According to the classification, the following provisioning schemes were applied; $0.5 \%$ of normal credits, $1 \%$ of precautionary, $20 \%$ of substandard, $100 \%$ of doubtful and estimated loss credits. Banks were allowed up to five years ('94-'98) to comply with the new scheme. From July 1998, the provisioning scheme was strengthened to $2 \%$ of precautionary credits. The classification criteria for precautionary and substandard credits were also strengthened from July 1998.

${ }^{11}$ Additional provisions to satisfy $100 \%$ of required loan loss allowances will decrease the BIS ratio as well as the capital to total asset ratio although the loan loss allowance is counted as tier II capital in computing the BIS ratio. This is because the tier II capital is allowed to be counted as capital only up to $50 \%$ of the basic capital. Later in 1998, the supervisory authority announced that the loan loss allowances be totally excluded from the tier II capital in computing BIS ratios from January 1999.
} 
categories; normal, precautionary, substandard, doubtful, and estimated loss. From July 1998, the substandard and below category was strengthened to include assets with interest payments in arrears by no less than 3 months from the previous 6 months criteria, and precautionary asset category to include assets in arrears by no less than 1 month from the previous 3 months criteria. Hence, the adjusted bank capital measures up to 1997 in Table 5 are still upper bound measures. In addition, from January 2000, forward-looking criteria of asset classification will be introduced in an attempt to upgrade prudential supervisory standard to international best practices. Accordingly banks should accumulate additional loan loss allowances against loans extended to firms whose debt service capacity is in doubt regardless of the firm's actual status of interest payment deferral.

To obtain bank capital measures under a more consistent asset classification criteria and to diagnose asset quality deterioration more correctly, we need to make further adjustments for latent nonperforming loans. The existence of substantial, but officially not recognized, latent nonperforming loans means that the typical bank capital measures are over-estimated ones and this is the adjustment we turn to next.

One way to obtain a more consistent measure of bank asset quality is to assume a hypothetical asset classification criteria regardless of the official criteria, and then the size of bad loans could be estimated from corporate balance sheet data by applying the hypothetical criteria. A crude criterion to sort out bad loans would be the interest coverage ratio, EBITDA/Interest Payments, where EBITDA denotes earnings before interest payment and tax plus depreciation and amortization. If the interest coverage ratio is less than one, it means that the borrowing firm cannot meet interest payment with its operating cash flow. To do our calculation from the corporate firms that were subject to external audits (more than 6,000 firms), those firms whose interest coverage ratio was less than one were sorted out and the loans extended to those firms were accumulated. Note that some of the loans extended to the firms with interest coverage ratio less than one might have already been classified as non-performing according to the official criteria. To figure out additional effect on the bank capital soundness, we need to focus on the loans of potentially nonperforming firms but not classified as non-performing yet according to the official criteria. For this purpose, those firms that actually went bankrupt subsequently were dropped from the sample, since loans of these firms are most likely to have been classified as non-performing. It is most likely that 
banks have not accumulated loan loss allowances against the loans of those potentially nonperforming but surviving firms as long as they were not deferring interest payments. ${ }^{12}$

Figure 1 shows the percentage of loans extended to the potentially non-performing firms out of total loan extended to the corporate firms under an external audit requirement. As can be seen from the figure, the ratio was rising in 1992-93 period, then decreased in the 1994-95 business cycle boom, and then was rapidly rising again in $1996-98$ period. As noted in Kim et al (1998), the problem with the decrease in the ratio in the 1994-95 period was that it was a temporary phenomenon largely driven by the boom in semiconductor exports. In fact the asset qualities of financial institutions kept deteriorating throughout the 90s and there was a false demand for credit because of substantial roll-overs of the loans of ailing firms. The increase in the latent NPL was partly due to inefficiencies in corporate exit mechanisms and partly due to government too-big-tofail policies of not allowing large firms to go into bankruptcy.

We now turn to getting a more realistic, but crude, estimate of the deterioration in asset quality on bank capital by allowing for latent non-performing loans. To obtain a more realistic measure of bank capital, we proceed in the following steps. First, we multiply the latent NPL ratio shown in Figure 1 by total financial credits extended to the corporate sector to obtain aggregate estimates of latent NPL. Second, to obtain the bank share of the aggregate latent NPL, we multiply the amount of the latent NPL by the aggregate bank share of total corporate borrowings, assuming that the latent non-performing loans were distributed symmetrically. Finally we assume an average $10 \%$ loan loss reserve ratio against this latent NPLs, and multiply this to the bank share of aggregate latent NPL to figure out the adjustment to bank capital. We chose the average $10 \%$ provisioning rate based on the following reasoning. Firms whose interest coverage ratio are less than one are most likely the ones that ultimately need loan restructuring, and from July 1999 restructured loans required provisions in the range of 2 (precautionary) to $20 \%$ (substandard). The calculations are summarized in Table 6.

The final row of Table 6 shows that bank capital to total bank asset ratio was steadily decreasing throughout the 1990's, as with the official figures in Table 3, but was at a much lower level. Once the deterioration in the bank asset quality is more consistently reflected in the bank

\footnotetext{
${ }^{12}$ See, Kim et al. (1998) for more detailed experiments on corporate distress in Korea in this direction.
} 
balance sheet, the poor shape of the Korean banking system before the crisis becomes much clearer. Namely, the ratio drops below the $4 \%$ minimum level as early as 1995 , and subsequently, the deterioration of bank capital adequacy turned out to be quite dramatic, with capital ratios falling to $3.52 \%$ in 1996 and $2.26 \%$ in 1997 . Clearly, the official data reported in Table 3 gave a very distorted picture of what was happening to bank balance sheets.

Now we turn to financial market indicators of the health of banks, namely, whether the deterioration of bank balance sheets and profitability was detected in the stock market despite overestimates of bank capital in the reported financial statements of banks. Figure 2 shows the stock market performance of banking industry (BI), financial industry as a whole (FI), and overall stock market index (KOSPI). As we can see from the figure, up to 1993, the overall market index and index for banking industry moved nearly in tandem. However, from 1994 on, the bank stock price index began to under-perform the overall market index by a significant margin. Note that the effect of business cycle boom in the 1994-95 period which was reflected in the rise in the overall market index cannot be observed in the banking industry index indicating that the stock market was correctly perceiving the long-lasting potential bad loan problems in the bank balance sheet.

Another feature of the balance sheets of banks and other financial institutions is also important to how the financial crisis played out. As is shown in Figure 3, the external liabilities of financial institutions grew rapidly throughout the 1993-1996 before crisis period. The large amount of external liabilities of financial institutions before the crisis made them very vulnerable to declines in the value of the won (both directly through unhedged position of financial institutions and indirectly through the corporate sector), and as the asymmetric information view indicates, this could have been an important factor triggering a full-blown financial crisis at the end of 1997 and early 1998.

Although the commercial banking industry is our main concern, merchant banking corporations, a specific group of non-bank financial institutions, deserve special mention. Merchant banking corporations are wholesale financial institutions engaging in underwriting securities, leasing and short-term lending to corporate sector by funding themselves from issuing bonds and commercial paper and borrowing from inter-bank and foreign markets. In 1990 there were only six merchant banking corporations and all of them were foreign affiliated. However 
from 1994, as a result of financial liberalization policies unveiled in 1993, the barrier to entry in the merchant banking industry was effectively lowered and its business area was comprehensively expanded. By the onset of 1997 financial crisis, a total of 30 merchant banking corporations were in business dominating the commercial paper issuing and discounting market. During the financial crisis, more than $50 \%$ (17 out of 30 ) of those corporations were permanently closed.

The problems associated with merchant banking corporations highlight a key aspect of the Korean financial crisis. While maintaining relatively tight supervisory standards for the commercial banks, the supervisory authority applied a much more lenient regulatory regime for this non-bank financial industry. ${ }^{13}$ Without tight supervisory regulations, the merchant banking corporations engaged in increasingly risky business and exposed themselves to significant interest rate, currency and credit risks by exploiting financial liberalization and deregulation that accelerated from 1995. The loan concentration to big business conglomerates (chaebols) was relatively high; they often borrowed short-term at low interest rates and invested in relatively long-term high yield assets; and they even engaged in various off-balance sheet transactions related with risky offshore, lower credit country products. At the end of 1996, the non-performing loan to capital ratio of the merchant banking corporations was as high as $31.9 \%$ while the ratio was $12.2 \%$ in the commercial banking sector. This clearly reveals that deterioration in asset quality and balance sheet soundness had been even more problematic in the merchant banking industry.

\section{Balance-Sheet Fundamentals: The Corporate Sector}

Another important source of structural vulnerability was the highly leveraged corporate financial structure. As we can see in Figure 4, the corporate debt to GDP ratio was gradually increasing until 1995. However, after that, the ratio increased substantially and reached over 1.5 in 1996 and 1.7 in 1997 . The debt to equity ratio was also extremely high, around the 2.5 level in

\footnotetext{
${ }^{13}$ The merchant banking corporations were supervised by the Ministry of Finance and Economy, while the commercial banks were under the supervision of Bank of Korea. Due to the nature of merchant banking corporations which do not accept direct deposits, minimal supervisory regulations were applied. For example, merchant banking corporations were not subject to the strict ownership regulation applied to banks, which resulted in the ownership of many merchant banking corporations by chaebols. Regulations and guidance on interest rates were much more lenient, allowing a greater capability to compete with banks by offering quasi-deposit products. Also, there existed no tight capital adequacy
} 
the 1990s for all listed companies and an even higher 4.0 for the top 30 chaebols. Due to the high leverage largely driven by the over-investments of conglomerates, the corporate sector became increasingly vulnerable to unfavorable shocks.

Table 7 shows three profitability indices for the corporate sector during the 1990s. In 1996 there was a sharp decline in corporate profitability, as evidenced by the fall off of return on assets, return on equity and the growth rate of operating income. This dramatic decline in profitability was mainly due to a negative terms of trade shock to be discussed below. Table 8 gives a more detailed breakdown of the return on assets of the thirty largest chaebols. It shows that the profitability picture for the smaller chaebols was particularly weak, even during the boom years of 1994-95.

Additional evidence on the deterioration of corporate balance sheets before the crisis can also be seen in Figure 1, described above, which shows the percentage of loans to firms that had an interest coverage ratio less than one. Note again that the ratio increased rapidly during the 1991-93 period, but decreased to its previous level during the 1994-95 boom period, but rose again in 199697. This might indicate that the deterioration in 1996-97 period was due to business cycle factors rather than structural problems. However, as Kim et al. (1999) showed, if we exclude semiconductor sectors the ratio was increasing steadily, and profitability was also deteriorating steadily. $^{14}$

Another possible reason for the structural deterioration in profitability before the crisis is increasingly inefficient corporate investment. One commonly used measure of aggregate investment efficiency is the incremental capital output ratio (ICOR). The incremental capital output ratio is the ratio of investment to the change in output, usually measured as cumulative investments relative to the change in output over a period of 5 years or more. If investment and capital allocations are efficient, output will grow more given the same level of investment, and hence, the ICOR will be lower. For example, the international financial community regards an ICOR on the order of five or less a "good" standing, while lending is viewed as dangerous if a country's ICOR is above this. Figure 5 shows the trend in ICOR computed from previous 5 years' cumulative investment and output changes. It has increased to a level of more than 6 in 1992 and

regulations such as the BIS standards applied to commercial banks.

${ }^{14}$ Also Table 8 indicates that the profitability increase in the 1994-95 boom was largely limited to the 
remained at the level since 1992. Although this is an aggregate measure, the ICOR indicates that, relative to the $80 \mathrm{~s}$, the efficiency of corporate investment substantially decreased in the 90s, which in turn, brought about a structural deterioration in corporate profitability.

Figure 6 shows the yearly corporate financing (flows) by financing sources from the flow of funds account. Note that the net size of annual financing decreased sharply in the second quarter of 1997, after the default of Hanbo group. This was the first time that a chaebol actually underwent a bankruptcy driven by market forces. Net borrowings from the financial intermediaries decreased steadily throughout 1997 and since the second quarter of 1998, the corporate sector actually repaid its existing loans more than new borrowing. Net borrowings from foreign sources turned to negative from the fourth quarter of 1997, when the stock prices in South-East Asian countries collapsed.

Table 9 shows stocks of corporate debt by financing sources. Note that the bank share decreased from nearly $23 \%$ in 1990 to $20 \%$ in 1998 . The share of non-bank financial intermediaries increased up to $24.3 \%$ in 1994, although it decreased from 1995 on as the share of corporate bond and commercial paper increased during the period. It also shows that the share of foreign borrowing steadily increased before the crisis, although the dramatic increase in 1997 is largely due to the exchange rate depreciation.

Table 10 shows foreign currency denominated debts in the corporate sector. Note the foreign source in Table 9 corresponds to external debts in Table 10. To figure out the foreign currency denominated debts for the corporate sector, we need to add to external debt, the foreign currency loans extended from domestic financial institutions. Foreign currency loans from domestic financial intermediaries rose rapidly from 1994 on. This implies that external borrowings of financial intermediaries were in turn loaned to the corporate sector so that most of the foreign exchange risks were transferred to the corporate sector. The seventh row of the table shows that the total foreign currency denominated debt in the corporate sector was increasing dramatically before the crisis implying a potentially significant exchange rate exposure of the corporate sector.

To figure out exact degree of exchange rate exposure, we need to focus on the net foreign currency denominated debt in the corporate sector. Assuming that the whole foreign currency

top five chaebols. 
deposits at commercial banks were made by the corporate sector, a conservative measure of the net domestic foreign currency debt can be obtained by subtracting domestic deposits in foreign currency from foreign currency loans from domestic financial institutions. Then, the net foreign currency denominated debt is the sum of net external debt and net domestic foreign currency debt. As the calculation in the ninth row of Table 10 shows, net foreign currency debt accounted for more than $60 \%$ of the total foreign currency denominated debt before the crisis. Note that we adopted a conservative measure by assuming that all of the foreign currency deposits were made by the corporate sector and not by households and financial institutions. This implies that at least $60 \%$ of the corporate foreign currency debts were not hedged against exchange rate fluctuations. However, as the calculation in the final row of the table shows, the share of foreign currency denominated debt out of total corporate debt was around $10-12 \%$ before the crisis, and this small share implies that the effect of exchange rate depreciation on corporate balance sheets should not be exaggerated.

\section{Why Did Balance Sheets Deteriorate?}

We have documented above the deterioration of balance sheets of both the banking and corporate sectors that developed before the onset of the Korean financial crisis, which the asymmetric information view indicates is a key element in the development of financial crises. However, a key question naturally follows: What caused balance sheets to deteriorate?

Financial liberalization is often cited as the primary impetus for the subsequent credit expansion and hence deterioration of the bank asset quality leading up to financial crises. Korea had liberalized its financial system and opened up its capital market gradually throughout the 1990s. The liberalization process accelerated since 1995 in an attempt to fulfill the requirements to obtain OECD membership. How important a role did Korea's financial liberalization play in the deterioration of bank balance sheets?

Credit growth in Korea was quite rapid before the crisis as Figure 7 indicates, which shows the level of domestic credit of financial institutions in both real terms and relative to GDP. Although domestic credit rose to nearly $200 \%$ of GDP, and real domestic credit more than quadrupled in the decade preceding the crisis, there does not appear to be a pronounced increase in the trend after financial liberalization occurred. Although the rapid credit growth may have 
contributed to the deterioration in the balance sheets of the financial sector because financial institutions could not hire and train loan officers fast enough, the source of the rapid lending growth may be due to other factors than financial liberalization. In addition, although credit growth in Korea was high before the crisis, it was not as rapid as in Mexico or other East Asian countries before their crises. ${ }^{15}$

Although financial liberalization may have not been as critical to creation of a lending boom as in other emerging market countries that have experienced a crisis, it did play an important role in increasing the exposure of financial institutions to foreign exchange risk. One impetus to increased short-term foreign borrowing by financial institutions were aspects of the financial liberalization process. In 1993, the Korean government expanded the list of usage for which financial institutions could provide foreign-currency denominated loans. Short-term foreign borrowing by financial institutions was allowed at the time, while the government maintained quantity restrictions on longterm foreign borrowing as a means of capital flow management.

The result was a dramatic increase in short-term foreign debts of financial institutions to finance strong investment demand of the corporate sector as the economy entered a boom in 1994. In addition, the number of financial institutions engaging in foreign-currency-denominated activities increased sharply with financial liberalization. From 1994 to 1996, a total of 24 finance companies were transformed into merchant banking corporations, which meant a corresponding increase in the number of participants in international financial markets because merchant banks were allowed to engage in foreign exchange transactions, while finance companies were not. During the same period, Korean banks opened 28 foreign branches which gave them greater access to foreign funds. These changes in the institutional framework contributed importantly to the rapid growth in foreign-currency borrowing by financial institutions and businesses documented above.

Financial liberalization also played an important role in producing the deterioration in financial sector balance sheets. While regulations on financial institutions were being relaxed in order to enable them to engage in a wider set of activities, an implicit government safety net for financial institutions along with weak prudential supervision led to excessive risk-taking. The result was the growing bad loan problems documented above and deterioration of financial

\footnotetext{
${ }^{15}$ See Corsetti, Pesenti and Roubini (1998) and Mishkin (2000).
} 
institutions' balance sheets.

A source of moral hazard that helped produce a deterioration in both financial and nonfinancial balance sheets was government involvement in the credit markets which created the impression that the chaebols were "too big to fail". We have seen that these conglomerates had huge leverage, and lending to them increased in the 1990s despite the weakness of their profitability. Financial institutions kept lending to them because they expected that the government would not allow these firms to go bankrupt, thus in effect guaranteeing their loans. The result was excessive borrowing by the chaebols, which produced bad loans down the road. Under the regime, there existed no strong incentives for commercial banks to improve their own credit analysis and risk management capabilities. Bank managers often decided on credit extension according to the size of borrowing firms under the assumption of 'too-big-to-fail' argument. Naturally credit concentration toward chaebol made banks vulnerable to unfavorable shocks. This tendency was stronger for the bigger and older commercial banks such as the Korea First, Seoul, Hanil, and Commercial Bank of Korea, all of which were nationalized throughout the recent bank restructuring process.

The moral hazard problem was even more dramatic for non-bank financial institutions. Because they were largely independent from the government, supervisory standards and monitoring of prudential regulations were extremely poor. While the central bank had the supervisory authority for commercial banks, the supervisory system for non-bank financial institutions was fragmentary without explicit accountability. The absence of limitations on ownership has resulted in the situation where a significant portion of non-bank financial institutions was owned by chaebol. ${ }^{16}$ The lower supervisory standards and poor monitoring resulted in various illegal off-balance sheet transactions to exploit the funds of affiliated financial institution for other ailing subsidiaries. ${ }^{17}$ As we mentioned earlier, an adequate supervisory

\footnotetext{
${ }^{16}$ For instance, as of March 1998, the top 5 chaebols controlled more than 30 non-bank financial institutions, and their market share was more than $30 \%$ in terms of assets of non-bank financial industry.

${ }^{17}$ For example, Daehan Life Insurance, the third largest life insurance company in Korea, extended credits of more than 3 trillion won to related subsidiaries of its parent company during the 96-98 period, violating regulations on the related loans. The life insurance company was in a net debt position by more than 2 trillion won, and in August 1998, the financial supervisory authority ordered 100\% write-offs of existing equity to inject public funds. Similar cases are bankruptcies of Daehan Merchant Bank and
} 
framework for merchant banking corporations had not existed. The absence of prudential regulations on the liquidity position of merchant banking corporations and resulting maturity mismatch problems for foreign assets and liabilities played a critical role in triggering the currency crisis in December 1997.

Another impetus to excessive risk-taking on the part of Korean financial institutions, was that foreign lenders to them were not given sufficient incentives to monitor the Korean institutions because they assumed, quite rightly as it turned out, that they would suffer only minor losses if the Korean financial institutions got into trouble. Either they would be protected from loss by the Korean government or by international institutions like the IMF who would provide the necessary funds to bail them out.

A major shock to balance sheets occurred as a result of a terms of trade shock to the Korean economy in 1996. As can be seen from Figure 8, the terms of trade deteriorated by approximately $20 \%$ in $1996-97$ period, the largest drop since the first oil shock of 1974-75. The prices of major export goods such as semi-conductor chips, steel and chemical products fell significantly during the period. For example, the unit price of semi-conductor chip fell by more than $70 \%$.

The terms of trade shock, which put unduly heavy pressures on already thin profit margins of chaebols and their closely tied small- and medium-sized firms, began to be realized as major corporate bankruptcies in $1997 .^{18}$ The monthly average number of firms defaulted on promissory notes during 1997 was 1,431, nearly a 50\% increase from 966 in 1996, indicating the degree of vulnerability of the economic structure.

Another important shock to the Korean economy occurred with the bankruptcy of Hanbo on January 23, 1997, the fourteenth largest chaebol. This bankruptcy indicated that the era of "too-big-to-fail" for the chaebols was over and that the terms of trade shock might require a large-scale adjustment of the corporate sector. Indeed, the bankruptcy of Hanbo was just the beginning. Five others of the thirty largest chaebols went bust in 1997: Sammi, the $25^{\text {th }}$ largest

Dongseo Securities, among others, which became insolvent due to the credits extended to ailing parent and its affiliated companies.

${ }^{18}$ According to Cho (1999), the terms of trade deterioration by $20 \%$ accounts for approximately more 
on March 19, Jinro, the $19^{\text {th }}$ largest on July 15 , Haitai, the $24^{\text {th }}$ largest on November 1 and NewCore, the $28^{\text {th }}$ largest on November 4.

A result of the greater uncertainty created by these bankruptcies and the deteriorating condition of both financial and non-financial balance sheets, the stock market in Korea fell sharply. From a peak value of 980.9 at the end of April 1996, the Korean stock market index fell to 677.3 by the end of March 1997, a decrease of more than 30\%. The stock market improved a little bit, but with subsequent bankruptcies of chaebols throughout 1997, the KOSPI dropped to 470.8 at the end of October even before the outbreak of the currency crisis.

The facts of the run-up to the Korean financial crisis fit in with the asymmetric information story quite nicely. As we have seen, an increase in uncertainty and a decrease in net worth as a result of a stock market decline and deterioration in corporate balance sheets increase asymmetric information problems. It became harder to screen out good from bad borrowers, and the decline in net worth decreased the value of firms' collateral and increased their incentives to make risky investments because there was less equity to lose if the investments are unsuccessful. The increase in uncertainty and stock market declines that occurred before the crisis, along with the deterioration in financial sector and corporate balance sheets, therefore worsened adverse selection and moral hazard problems and made the Korean economy ripe for a serious financial crisis.

\section{The Second Stage of the Korean Crisis: Speculative Attack and Policy Responses}

Given the weakness of financial sector balance sheets and the increased exposure of the economy to foreign exchange risk because of the large amount of external borrowing, Korea was ripe for a speculative attack on its currency. With the collapse of the Thai baht in July and the announced suspension of forty two finance companies in Thailand in early August 1997, which indicated the depth of the problems in the financial sector in that country, issues began to be raised whether similar problems existed in Korea. As we have seen in Section II, problems in the financial sector make it very difficult for the central bank to defend the currency and this in itself

than $70 \%$ loss in aggregate corporate profits. 
can stimulate a speculative attack. Thus it is not surprising that with the vulnerability of the Korean financial sector and the developments in Thailand and elsewhere in East Asia the Korean won would be attacked. With the collapse of Asian stock markets and the downgrading of Korea's sovereign credit rating at the end of October, the attacks became even more serious and on November 21, 1997, the Korean government announced that it would ask for assistance from the IMF to overcome mounting foreign exchange problems and rapid deterioration of the nation's credit standing.

Note that the speculative attack was not in the usual form of direct currency attack to exploit expected depreciation. Due to the tight regulation on currency forwards which had to be be backed by corresponding current account transactions and the absence of currency futures market inside Korea at that time, opportunities for direct speculative attack had been limited. Rather, the drastic depreciation of Korean won was driven by foreign creditor's run on Korean financial institutions and chaebols to collect their loans, and by foreign investors to exit from the Korean stock market. ${ }^{19}$

Table 11 shows trends of official foreign exchange reserves prior to and during the crisis episode. The last row indicates the usable amount of foreign exchange reserves, which is obtained by subtracting the amount of central bank's deposits at overseas branches of domestic financial institutions from official figure. The central bank supplied foreign exchange to banks in the form of overseas branch deposits as Korean banks found it increasingly difficult to refinance foreign debts due to significantly deteriorated credit standings. While the overseas deposits were not practically usable, the monetary authorities only announced the total amount of foreign exchange reserves, and this caused the spread of devastating rumors among international financial investors as to the actual size of usable foreign exchange reserves.

This policy mistake was followed by another. The merchant banking corporations were in particular trouble when the financial crisis developed, because many of them had increased

\footnotetext{
${ }^{19}$ Shin (1998) shows that credits collected by foreign creditors from the Korean financial institutions and their overseas branches during the month of November 1997 amounted to $\$ 15.5$ billion, while the sum of net outflow of foreign stock investments and errors and omission on the balance of payment account was $\$ 3$ billion. Based on the evidence and assuming that the errors and omission roughly indicates capital flight amounts by domestic residents, Shin argues that direct speculative attack played a
} 
their exposure to South East Asian countries, particularly Thailand during 1995 and 1996. Instead of closing these institutions down, these institutions received liquidity both from the Bank of Korea and from banks who were encouraged to lend to these corporations. Combined with liquidity supplied to the banking sector, the result was that net domestic credit expanded during November and December as is shown in Figure 9.

This policy had two negative outcomes. First, it convinced the market that the Korean government was willing to bail out financial institutions without providing a serious plan to remedy the fragility of the financial sector. Restoring confidence to the financial markets is crucial in order to promote recovery, yet the government's policy toward the problems of the commercial banks and merchant banking corporations significantly eroded confidence in the government's ability to manage the financial sector. Second, the expansion of net domestic credit indicated that the Korean government was unwilling to take the necessary steps to defend the currency, just as occurred in Mexico, with the result that confidence in the government's ability to take the steps needed to strengthen the currency was weakened, thus making a larger depreciation of the won much more likely. As shown in Figure 10, from October to the end of 1997 the spot price of Korean won depreciated by 47\%, and yet the market was expecting further depreciation as evidenced by the large off-shore futures exchange premium at the end of 1997.

With the sharp depreciation of won, as shown in Figure 11, the market interest rate also soared to over $20 \%$ by the end of 1997 , which was largely driven by the IMF advised policy to stabilize the foreign exchange market. High interest rates have serious negative consequences for the economy, both because of their direct effects on spending through the cost of capital, but also because of the cash flow effects which weaken balance sheets and increase asymmetric information problems in the credit markets. As a result, bankruptcy rate of smaller chaebols and small and medium-sized companies skyrocketed as represented by the historically high dishonored bill ratio at the end of $1997 .^{20}$

However, as was seen in Table 1, the financial crisis in Korea led only to a small increase in inflation, so that interest rates came back down quite quickly. By the fall of 1998, they were

limited role in triggering the 1997 Korean currency crisis.

${ }^{20}$ The dishonored bill ratio is the percentage of corporate promissory notes, checks and bills in default 
actually at levels below those prior to the crisis. Behind the relatively quick stabilization of the inflation and interest rate, drastic falls in domestic demand played a key role. In fact, in the second quarter of 1998, deflation, rather than inflation, was a concern for policymakers since it would increase real burden of debtors and make debt restructuring more difficult. According to Korea Development Institute's (KDI) internal estimates, the demand driven component of inflation, where supply side effects such as depreciation were eliminated, indicated a possibility of serious deflation beginning at that time. Indeed, from the second half of 1998, the Bank of Korea changed its monetary policy stance from contractionary to reflationary to facilitate the restructuring process.

The inflation developments in Korea were quite different from those in Mexico and Indonesia during their crises, and so the cash flow mechanism resulting from high interest rates that promotes financial instability was not as operational. This may be one of the reasons why the Korean economy has been recovering so rapidly, as indicated by the rapid growth in industrial production in 1999 shown in Figure 12.

Because both firms and financial firms had so much foreign-currency debt, when the won lost $47 \%$ of its value, the asymmetric information analysis indicates both financial and nonfinancial firms' balance sheets would worsen, which would cause a significant increase in adverse selection and moral hazard problems. To see if this story makes sense we examine the effect of exchange rate fluctuations on the stock price indices of various financial industries. We do this by regressing stock price indices on the depreciation in the exchange rate (DEP) and the market return (RMKT) to allow for CAPM type effects. Instead of accounting measures, we decided to use stock prices to diagnose the effect of exchange rate depreciation because any measure constructed from the balance sheets (including off-balance sheet items) cannot appropriately capture the indirect effect of exchange rate fluctuations. In addition, at least for banks, the reported book measures indicated no significant open net position as to foreign assets and liabilities since banks have been under tight supervisory regulation not to maintain a significant open position.

As can be seen in Table 12, it seems that the banking industry was less exposed to exchange out of total promissory notes, checks and bills cleared at the clearing house during the day. 
rate fluctuations than merchant banks and securities companies. Bank returns do respond negatively to depreciations, but the coefficients on DEP are not statistically significant. On the other hand, for the merchant bank and securities industries, the coefficients on DEP are significantly negative, even when we include the market return, RMKT, as another explanatory variable. $^{21}$ With the gradual financial market liberalization in the $90 \mathrm{~s}$, the non-bank financial industries were increasingly involved with foreign currency transactions, especially borrowing short-term from foreign source and lending long-term to local firms, thus leaving them with a net external liability position. They were also not subject to effective prudential regulations and supervision to limit their foreign exchange risk and thus it is not surprising that their returns had a stronger response to exchange rate movements.

The exchange rate exposure of the corporate sector was much more significant relative to the financial industries. In Table 10 we have already seen that at least $60 \%$ of foreign currency denominated debt in the corporate sector was not hedged in 1996. According to the estimate of the Korea Stock Exchange, as of December 1997, the net foreign currency debts of all listed companies amounted to 54.7 trillion won. Based on this estimate and given the $47 \%$ depreciation during the last two months of 1997, the exchange rate devaluation loss during the two months would amount to 17.5 trillion won, which was nearly $17 \%$ of the entire equity capital for the non-financial listed companies in Korea.

\section{Summary}

The data and events in the Korean crisis seem to generally accord well with the story told by the asymmetric information analysis of financial crises. However, the Korean experience does differ in some details from the generic, asymmetric information story and from the experience in some crisis countries. In contrast to the experience in Mexico and Indonesia, Korea

\footnotetext{
${ }^{21}$ Using Panel data, Hahm and Yoo (1999) provides more detailed empirical evidence on the degree of foreign exchange exposures of Korean financial institutions in the 1990s.
} 
did not have much inflation after the currency depreciation, and this may help explain why the recovery in Korea has been relatively rapid. Furthermore, although financial liberalization had an important role in the Korean crisis, it is not as clear that it led to a lending boom similar to that in Mexico or other East Asian crisis countries. The rapid growth of credit predated the financial liberalization, and credit growth was somewhat less than than in other crisis countries just before the crisis. Nonetheless, even though rapid credit growth was not as clearly driven by financial liberalization, in an environment of poor supervision of the financial sector, substantial credit growth over a long period of time still led to the accumulation of bad loans which substantially weakened the balance sheets of financial institutions and promoted the financial crisis. On the other hand, financial liberalization in Korea did make it easier for financial institutions to increase their exposure to foreign exchange risk, increasing the fragility of the Korean financial system.

\section{SOME EVIDENCE ON THE EFFECT OF CREDIT MARKET CONDITIONS ON THE ECONOMY}

In this section we examine more direct financial market evidence to explore the degree of information asymmetry which plagues efficient credit allocations. Recent literature on the credit view of monetary policy implies that when a credit crunch occurs due to bank credit supply shocks, such as binding capital regulations or heightened information asymmetry, two credit market variables would respond: the spread between interest rates on bank loans and alternative financial instrument, or the quantity mix of corporate financing tools. We look at each in turn. Note however, that the asymmetric information analysis of financial crises sees effects of asymmetric information not just through bank lending, but through other channels as well. ${ }^{22}$ Thus the evidence presented here is only of a partial nature and cannot give the full picture on the effects of information asymmetry on credit markets. In addition, the evidence here is of a time-series nature, which is not always easily interpretable because it is hard to be confident in the identification schemes necessary to interpret the results. Although we have some serious qualms about the time-

\footnotetext{
${ }^{22}$ See surveys in Hubbard (1995), Bernanke and Gertler (1995), Cecchetti (1995) and Mishkin (1996b), for example.
} 
series evidence here, we believe it is useful because the results for Korea are in accord with findings for the United States. There is a much more substantial evidence, both time-series and crosssection, supporting the credit view in the United States, and so the fact that we find some of the same evidence in Korea suggests that a credit crunch phenomenon was an important feature in Korea during the crisis period.

Figure 13 shows the spread between marginal bank lending rate (interest rates on bank overdraft loan: IOD) and yield on three year corporate bonds (YCB). We also examined commercial paper rates instead of $\mathrm{YCB}$, but the behavior of the spread is qualitatively the same. Note that the spread was relatively high in the second half of 1996, then decreased slowly, and increased sharply at the end of 1997 when the currency crisis occurred. The spread fell back to the normal level in the second half of 1998 when the monetary policy stance changed from contractionary, with high interest rates, to a more reflationary stance with lower interest rates.

Now let's turn to the behavior of corporate financing mix variable. In the literature, the ratio of short-term bank loans to the sum of short-term bank loan and commercial paper has been suggested as an indicator of the degree of bank credit supply shocks (Kashyap, Stein and Wilcox (1993)). (As these authors are aware, the identification condition for the validity of this ratio representing bank credit supply shocks depends on the assumption that shocks to loan demand affect bank dependent and nondependent borrowers equally, a not uncontroversial assumption.) In Korea, commercial paper and corporate bonds were used as alternative financing tools for bank loans, and therefore, we adopt instead the ratio of bank loans to the sum of bank loans, commercial paper and corporate bonds. Figure 14 shows the trend in the corporate financing mix. Note that the ratio was low during the 1995-96 period, it increased substantially in 1997, and then decreased to negative levels in 1998 (bank lending turned negative in the second half of 1998 when more loans were retired than new loans were extended).

Based on the combined evidence from those two figures, it appears that there was a modest bank credit restriction in the second half of 1996, but a serious credit crunch did not occur until the first half of 1998, that is, a period of unusually high interest rates. At first, it is rather puzzling that we could not observe unusual bank credit behavior at the onset of the crisis in the second half of 1997. At that time, bank loans actually increased, yet this is at least partially due to the government 
bail out policy. In April 1997, the government introduced a default prevention policy in a form of agreement among creditor banks and merchant banks to roll-over credits of ailing companies whose bank borrowing was more than 250 billion won. In the fourth quarter of 1997, the government introduced an additional bail-out policy measure in which banks extended syndicated loans of approximately 1.5 trillion won to six ailing chaebols. The bail-out policies and implicit government interventions distorted the prices and quantity of bank loans during the crisis, and hence it is rather difficult to obtain reliable evidence from market variables during this period.

Due to this difficulty, we turn to examining less-distorted private curb market conditions for small and medium-sized firms (SMEs) that are more bank-dependent. Table 13 collects some indicators of financing conditions for SMEs from the annual survey conducted by Kookmin Bank. The survey covers small and medium-sized manufacturing industries, excluding the tobacco manufacturing industry. The percentage of bank and non-bank borrowings out of total yearly financing fell sharply in 1997, and instead, the percentage of private curb loan financing increased from previous $2 \%$ level to $6.3 \%$. The share of bank loans without collateral (namely, on pure credit terms) out of total bank loans also fell sharply from $20 \%$ to $8.3 \%$ in 1997 . The curb loan rate spread for smaller versus larger SMEs increased and the average maturity of curb loans became much shorter in 1997. (The share of loans with less than 2 months maturity increased dramatically from $7.2 \%$ in 1996 to $66.4 \%$ in 1997.) All of these suggest that there was a severe credit crunch during 1997, at least for the SMEs.

Another interesting point emerges from the survey on the most important impediment in financial management. During the 1993-95 period, the decreasing profit margin was the most cited as the number one impediment, implying that decreasing profitability was a continuous problem throughout the 1990s. In the 1996-97 period lagged collection became the most cited impediment, indicating the increasing degree of cash flow and trade credit problems.

Figure 15 shows the growth rates of private credit and loans and indicates a sharp decline during the crisis period from late 1997 to 1998. However, in order to identify the degree of credit crunch more carefully, we would need to decompose the demand driven and supply driven components out of credit movement. The reduction in bank credits in 1998 shown in Figure 15 may well result from the fall in credit demands rather than credit supplies, resulting from the severe 
economic contraction during the crisis episode. In Table 14, we examine the time series behavior of real bank credit using aggregate data. We chose two dependent variables - the growth rates of real bank private credit and real bank loans. ${ }^{23}$ As explanatory variables, we used the industrial production growth rate representing the level of economic activity, the real money supply (M2) growth rate, real interest rate, and other supply side variables such as dishonored bill ratio representing the level of market uncertainty, and the bank capital growth rate. ${ }^{24} \mathrm{We}$ also investigated whether the credit behavior shows a differential behavior during the crisis period starting from November 1997 when Korea requested IMF assistance.

As expected, the industrial production growth, real interest rate, and the growth rate of real bank capital are significantly positively related to bank credit growth, while the money growth rate and dishonored bill ratio seem to be negatively correlated. It is interesting to note that the negative impact on bank credits of an increased dishonored bill ratio is mostly coming from the unusual behavior during the crisis period, implying that high uncertainty regarding the possibility of bankruptcy played an important role to cause credit crunch in the crisis episode.

In Table 15 we examine the portfolio composition of bank assets rather than the growth of bank credits. As can be seen in Figure 16, during the crisis episode, both the ratio of private credit to total bank asset (PC/ASSETS) and the ratio of loans to private credit (LOAN/PC) fell while the PC/ASSETS ratio fell more sharply. This occurred because banks shifted their portfolio composition towards safer government securities and more liquid instruments. The shift in the composition of bank assets itself could be an important indicator of credit crunch. However, given the endogenous nature of the composition variables because a slowdown in the economy leads to a drop in loan demand which lowers the ratios of private credit to bank assets and loans to private credit, we further investigate the determinants of those variables.

As can be seen in Table 15, the real interest rate and dishonored bill ratio seem to be important in explaining the bank private credit to asset ratio. Given the heightened level of

\footnotetext{
${ }^{23}$ The difference between real private credit and bank loans and discounts are securities, loans in foreign currency, and etc..

${ }^{24}$ In a rigorous sense, dishonored bill ratios and bank capital growth are also endogenous variables. We tried to employ a vector autoregression methodology to decompose the supply-side component of bank credit variables. However, due to the lack of sufficiently long data, the estimation results were not
} 
corporate default, banks tended to increase the share of government securities. Note that all of the effect comes from the crisis period, where banks under binding capital adequacy regulation prefer risk free assets whose BIS risk weight is zero. Note that the impact is weaker for the loan to private credit ratio, which is reasonable given that both private securities and loans are subject to similar credit risks. In sum, we see that banks, faced with a heightened level of uncertainty, did reduce the share of private credits out of total assets, and at the same time, reduced the share of illiquid loans out of private credits.

We now turn to the question of how and to what degree the changes in bank credit behavior affect the level of economic activity. To answer the question, in the spirit of Bernanke (1983) and Bernanke and Lown (1991), we estimated regressions with industrial production as the dependent variable, and credit variables as independent variables. The results are summarized in Table 16. Note that after allowing for the first lag of industrial production, the credit variables, both the growth variable and composition variable, have a significant impact on the level of economic activity. However again, one should exercise caution in interpreting this diagnostic result due to the possible endogeneity of these credit variables.

\section{POLICY LESSONS FOR KOREA}

Now that we have seen that asymmetric information analysis provides a useful explanation of the Korean data during the Korean financial crisis, we can ask what lessons the analysis might hold for Korean policymakers. There are two areas where these lessons are particularly pertinent: 1) prudential supervision and 2) monetary policy strategy.

\section{Prudential Supervision}

As we have seen, deterioration in financial institutions' balance sheets was a key factor that led to the Korean financial crisis, not only because of its direct effects, but because problems in the financial sector made the currency crisis more likely, which in turn led to a full blown financial crisis. Promoting strong prudential supervision to prevent excessive risk taking which

so stable. In this paper, we present only diagnostic results based upon a simpler estimation methodology. 
leads to a deterioration in financial sector balance sheets is thus crucial to preventing financial instability. Here we outline eight basic principles for establishment of a strong regulatory/supervisory system.

\section{1) Adequate Resources and Statutory Authority for Bank Regulators/Supervisors}

To do their job effectively, bank regulatory/supervisory agencies need adequate resources and the statutory authority (the ability to issue cease and desist orders and to close down insolvent banks). Without these resources, the bank supervisory agency will not be able to monitor banks sufficiently in order to keep them from engaging in inappropriately risky activities, to have the appropriate management expertise and controls to manage risk, or to have sufficient capital so that moral hazard incentives to take on excessive risk are kept in check. In this regard, there has been a major step forward to strengthen the financial supervisory system in Korea. On December 29, 1997, the long-awaited 13 financial reform bills including the bill to establish consolidated financial supervisory authority, were passed at the National Assembly. According to the bill, the Financial Supervisory Commission (FSC) was newly established in April 1998 and existing supervisory bodies were merged into a consolidated Financial Supervisory Service under the FSC. In addition, the Financial Industry Restructuring Act was amended so that the FSC and FSS be equipped with effective statutory authorities including the authority to order write-offs, mergers, suspension, and closures of ailing financial institutions.

\section{2) Prompt Corrective Action}

If banking crises and financial crises are to be avoided, quick action by bank supervisors to stop undesirable bank activities and, even more importantly, to close down institutions that do not have sufficient capital is critical. Regulatory forbearance which leaves insolvent institutions in operation, as occurred in Korea, is disastrous because it dramatically increases moral hazard incentives to take on excessive risk because an operating but insolvent bank has almost nothing to lose by taking on colossal risks and "betting the bank". If they get lucky and the risky investments pay off, they get out of insolvency. On the other hand, if, as is likely, the risky investments don't pay off, insolvent institutions' losses will mount, weakening the banking system further and leading to higher taxpayer bailouts in the future. Indeed, this is exactly what occurred in the Korean 
situation leading up to the financial crisis in 1997.

An important way to ensure that bank supervisors do not engage in regulatory forbearance is through implementation of prompt corrective action provisions which require bank supervisors to intervene earlier and more vigorously when a bank gets into trouble. Prompt corrective action is crucial to preventing problems in the banking sector because it creates incentives for banks not to take on too much risk in the first place, knowing that if they do so, they are more likely to be punished.

The outstanding example of prompt corrective action is the provision in the FDICIA (Federal Deposit Insurance Corporation Improvement Act) legislation implemented in the United States in 1991. Banks in the United States are classified into five groups based on bank capital. Group 1, classified as "well capitalized", are banks that significantly exceed minimum capital requirements and are allowed privileges such as insurance on brokered deposits and the ability to do some securities underwriting. Banks in group 2, classified as "adequately capitalized," meet minimum capital requirements and are not subject to corrective actions but are not allowed the privileges of the well-capitalized banks. Banks in group 3, "undercapitalized," fail to meet riskbased capital and leverage ratio requirements. Banks in groups 4 and 5 are "significantly undercapitalized" and "critically undercapitalized," respectively, and are not allowed to pay interest on their deposits at rates that are higher than average. Regulators still retain a fair amount of discretion in their actions to deal with undercapitalized banks and can choose from a smorgasbord of actions, such as: restrictions on asset growth, requiring the election of a new board of directors, prohibiting acceptance of deposits from correspondent depository institutions, prohibiting capital distributions from any controlling bank holding company, and termination of activities that pose excessive risk or divestiture of non-bank subsidiaries that pose excessive risk. ${ }^{25}$ On the other hand, FDICIA mandates that regulators must require undercapitalized banks to submit an acceptable capital restoration plan within 45 days and implement the plan. In addition, the regulatory agencies must take steps to close down critically undercapitalized banks (tangible equity capital less than 2\% of assets) by putting them in receivership or conservatorship within ninety days, unless the

\footnotetext{
${ }^{25}$ See Sprong (1994) for a more detailed discussion of the prompt corrective action provisions in FDICIA.
} 
appropriate agency and the FDIC concur that other action would better achieve the purpose of prompt corrective action. If the bank continues to be critically undercapitalized it must be placed in receivership, unless specific statutory requirements are met.

In Korea as well, prompt corrective action provisions for commercial banks, merchant banking corporations, securities and insurance companies were introduced in April 1998. According to the provision, banks are classified into 5 groups by the BIS ratio and comprehensive evaluation grading system, and the supervisory authority could impose various corrective measures similar to the above U.S. practices whenever banks' BIS ratio falls below $8 \%, 6 \%$, 4\% and comprehensive grade falls below the $3 \mathrm{rd}, 4 \mathrm{th}$, and insolvency grade. Initially the prompt corrective measures were largely discretionary. However, in June and November 1998, the prompt corrective action provisions were substantially improved to guarantee mandatory implementation eliminating discretionary rooms and to make the system more transparent.

A key element of making prompt corrective action work is that bank supervisors have the financial resources to close down institutions when they become insolvent. It is very common that politicians and regulatory authorities engage in wishful thinking when their banking systems are in trouble, hoping that a large injection of public funds into the banking system will be unnecessary. ${ }^{26}$ The result was regulatory forbearance with insolvent institutions allowed to keep operating, which ended up producing disastrous consequences. The Korean authorities engaged in exactly this kind of behavior, but this has also been prevalent in other countries including Japan and the United States.

Not only must weak institutions be closed down, but it must be done in the right way: Funds must not be supplied to weak or insolvent banking institutions to keep them afloat. To do so will just be throwing away good taxpayer money after bad. In the long-run, injecting public funds into weak banks does not deliver a restoration of the balance sheets of the banking system because these weak banks continue to be weak and have strong moral hazard incentives to take on big risks at the taxpayers' expense. This is the lesson learned from the U.S. experience in the 1980s. The way to

\footnotetext{
${ }^{26}$ In addition, banking institutions often lobby vigorously to prevent the allocation of public funds to close down insolvent institutions because this allows them to stay in business and hopefully get out of the hole. This is exactly what happened in the United States in the 1980s as is described in Mishkin (1998).
} 
recapitalize the banking system is to close down all insolvent and weak institutions and sell off their assets to healthy institutions with public funds used to make the assets whole. If this is not possible, there is a need for a public corporation, like the Resolution Trust Corporation (RTC) in the United States, which will have the responsibility to sell off the assets of these closed banks as promptly as possible, so that the assets can be quickly put to productive uses by the private sector.

To reduce moral hazard, it is also important that stockholders, managers and large uninsured creditors be punished when banks are closed and public funds are injected into the banking system. Protecting managers, stockholders and large uninsured creditors from the consequences of excessive risk-taking increases the moral hazard problem immensely and is thus highly dangerous although it is common. The FDICIA legislation also has addressed this issue by providing new legislative guidelines for the resolution of bank failures to minimize costs to the taxpayer and to impose costs on large uninsured creditors, as well as on stockholders and managers. FDICIA generally requires that the FDIC resolve bank failures using methods which produce the least cost to the deposit insurance agency. These changes in resolution methods do appear to alter the incentives for uninsured depositors (with over $\$ 100,000$ in an account) to monitor banks because they are now subject to losses. This may in part help explain why U.S. banks have increased their capital in recent years and appears to be a successful feature of FDICIA.

In general, Korea seems to be following the above principles of bank resolution. First, insolvent financial institutions have been closed down. In June 1998, five insolvent banks were closed down and assets and liabilities of those banks were transferred to sound banks through the purchase and assumption (P\&A) arrangement. Six ailing banks were merged into three large banks, and an announcement was made that two big banks (Korea First, and Seoul) would be sold-off to foreign investors. As of June 1999, 16 merchant banks, 5 securities companies, 4 insurance companies, 2 investment trust companies were closed down. Second, the Korean government has been implementing a comprehensive plan to support financial restructuring by procuring a total of 64 trillion won of public funds (approximately 16\% of GDP). Out of the 64 trillion won, as of June 1999, the Korea Asset Management Company (KAMCO) has spent 20 trillion won to purchase non-performing loans of closed and merged banks, and the Korea Deposit Insurance Corporation (KDIC) has spent 26.6 trillion for recapitalization and deposit insurance. In the process of the fiscal 
support, the Korean government has applied following burden sharing principles: First, shareholders capital must be reduced to the minimum level. Second, management must also be held accountable. Third, fiscal support is conditional upon the implementation of a comprehensive self-rescue plan. Accordingly, almost all of the banks now have new management and the number of bank employee has been reduced by $34 \%$.

However, there remain various difficulties to be overcome by the Korean government. First, the restructuring process up to now has been only first stage measures, especially given that further restructuring of the non-bank financial institutions such as insurance and investment trust companies needs to be conducted. The total fiscal cost for clearing up of non-bank financial industry and additional funds needed for bank recapitalization due to the introduction of the forward- looking asset-classification standard implies that the ultimate fiscal cost would far exceed the 64 trillion won allocated so far. Procurement of additional public funds is necessary for the government to avoid the above discussed regulatory forbearance policies and take a more decisive measure. Second, more transparent rules of fiscal support and penalties for getting the fiscal support are not yet sufficient. Currently, nearly absent is an effective ex-post monitoring mechanism for the aided financial institutions and strengthening this mechanism would help reduce the ultimate amount of tax-payer's money allocated. Finally, the recovery procedure of the disbursed public funds has been too slow. For example, KAMCO resold only 7.5 trillion won worth of non-performing assets out of the 20 trillion won purchased, and KDIC's re-privatization of subscribed bank equities has not yet begun. The markets would be reassured if a systematic and transparent re-privatization plan were announced and if this plan considered the optimal future financial industry structure that the government aims.

\section{3) Focus on Risk Management}

The traditional approach to bank supervision has focused on the quality of the bank's balance sheet at a point in time and whether the bank complies with capital requirements. Although the traditional focus is important for reducing excessive risk-taking by banks, it may no longer be adequate. First is the point that capital may be extremely hard to measure. Furthermore, in today's world, financial innovation has produced new markets and instruments which make it easy for banks and their employees to make huge bets quickly. In this new financial environment, a bank 
that is quite healthy at a particular point in time can be driven into insolvency extremely rapidly from trading losses, as has been forcefully demonstrated by the failure of Barings in 1995 which, although initially well capitalized, was brought down by a rogue trader in a matter of months. Thus an examination which focuses only on a bank's position at a point in time may not be effective in indicating whether a bank will in fact be taking on excessive risk in the near future.

For example, bank examiners in the United States are now placing far greater emphasis on evaluating the soundness of bank's management processes with regard to controlling risk. This shift in thinking was reflected in a new focus on risk management in the Federal Reserve System's 1993 guidance to examiners on trading and derivatives activities. The focus was expanded and formalized in the Trading Activities Manual issued early in 1994, which provided bank examiners with tools to evaluate risk management systems. In late 1995, the Federal Reserve and the Comptroller of the Currency announced that they would be assessing risk management processes at the banks they supervise. Bank supervision in Korea would be strengthened if Korea adopted similar measures to ensure that risk management procedures in their banks are equal to the best practice in banking institutions elsewhere in the world.

\section{4) Independence of the Bank Regulatory/Supervisory Agency}

Because prompt corrective action is so important, the bank regulatory/supervisory agency requires sufficient independence from the political process if it is to avoid the sweeping of problems under the rug and engaging in regulatory forbearance. One way to ensure against regulatory forbearance is to give the bank supervisory role to a politically independent central bank. This has desirable elements as pointed out in Mishkin (1992), but some central banks might not want to have the supervisory task thrust upon them because they worry that it might increase the likelihood that the central bank would be politicized, thereby impinging on the independence of the central bank. Alternatively, bank supervisory activities could be housed in a bank regulatory authority that is independent of the government. Korea has adopted the second approach taking the bank supervisory authority away from the Bank of Korea and housing it under a consolidated supervisory body. To promote independence of the supervisory authority, a committee system was introduced as implied by the name - Financial Supervisory Commission. In addition, the FSC was established under the office of the Prime Minister to ensure the separation of financial supervision from policy 
setting under the Ministry of Finance and Economy.

\section{5) Accountability of Bank Supervisors}

An important impediment to successful government regulation and supervision of the financial system arises because the relationship between voters-taxpayers on the one hand and the regulators and politicians on the other creates a particular type of moral hazard problem, the principal-agent problem. The principal-agent problem occurs because the agent (a politician or regulator) does not have the same incentives as the principal (the taxpayer they work for) and so act in their own interest rather than in the interest of the principal. Supervisors have incentives not to act in the taxpayers' interest and engage in regulatory forbearance, in which they do not enforce regulations and close down insolvent banks, because they often want to escape blame for poor performance by their agency. In addition, supervisors may want to protect their careers by acceding to pressures from the people who strongly influence their careers, the politicians.

This principal-agent problem can be minimized if bank supervisors are made accountable in order to improve incentives for them to do their job properly and not engage in regulatory forbearance. For example, as pointed out in Mishkin (1997b), an important but very often overlooked part of FDICIA which has helped make this legislation effective is that there is a mandatory report that the supervisory agencies must produce if the bank failure imposes costs on the Federal Deposit Insurance Corporation (FDIC). The resulting report is made available to any member of Congress and to the general public upon request, and the General Accounting Office must do an annual review of these reports. Opening up the actions of bank supervisors to public scrutiny makes regulatory forbearance less attractive to them, thereby reducing the principal-agent problem. In addition, subjecting the actions of bank supervisors to public scrutiny reduces the incentives of politicians to lean on supervisors to relax their supervision of banks. This element is largely missing from the current supervisory framework and practices in Korea, and an effective mechanism to strengthen supervisors' accountability needs to be introduced.

\section{6) Use of Market-Based Discipline}

There are two problems with relying on bank examiners to control risk-taking by banks. First, banks have incentives to keep information away from bank examiners so that they are not 
restricted in their activities. Thus even if bank examiners are conscientious they may not be able to stop the banks from engaging in risky activities. Second, is that because of the principal-agent problem, bank supervisors may engage in regulatory forbearance and not do their jobs properly.

An answer to these problems is to have the market discipline financial institutions if they are taking on too much risk. We have already mentioned that disclosure requirements are essential to the ability of the market to have the information which allows them to monitor financial institutions and keep them from taking on too much risk. Two additional steps may help increase market discipline. One is to require that banks have credit ratings. As part of the BASIC (which stands for bonds, auditing, supervision, information and credit ratings) supervisory system implemented in Argentina in December 1996 is the requirement that every bank have an annual rating provided by a rating agency registered with the central bank. ${ }^{27}$ Institutions with more than $\$ 50$ million in assets are required to have ratings from two rating agencies. As part of this scheme, the Argentinean central bank is responsible for performing an after-the-fact review of the credit ratings to check if the rating agencies are doing a reasonable job. As of January 1998, these credit ratings must be published on billboards in the banks and these ratings must also appear on all deposit certificates and all other publications related to obtaining funds from the public. As part of New Zealand's disclosure requirements, all banks must prominently display their credit ratings on their long-term senior unsecured liabilities payable in New Zealand, or alternatively, indicate if they do not have a credit rating. Clearly, the lack of a credit rating or a poor credit rating is expected to cause depositors and other creditors to be reluctant to put their funds in the bank, thus giving the bank incentives to reduce its risk taking and boost its credit rating. This has a higher likelihood of working in Argentina and New Zealand because both countries do not have government deposit insurance.

Another way to impose market discipline on banks is to require that they issue subordinated debt (uninsured debt that is junior to insured deposits, but senior to equity). Subordinated debt, particularly if it has a ceiling on spread between its interest rate and that on government securities, can be an effective disciplining device. If the bank is exposed to too much risk, it is unlikely to be

\footnotetext{
${ }^{27}$ See Banco Central de la Republica Argentina (1997) and Calomiris (1997) for a description of the Argentine BASIC system.
} 
able to sell its subordinated debt. Thus, compliance with the subordinated debt requirement will be a direct way for the market to force banks to limit their risk exposure. Alternatively, deposit insurance premiums could be charged according to the interest rate on the subordinated debt. Not only would the issuance of subordinated debt directly help reduce incentives for banks to engage in risky activities, but it can also provide supplemental information to bank examiners that can help them in their supervisory activities. In addition, information about whether banks are successful in issuing subordinated debt and the interest rate on this debt can help the public evaluate whether supervisors are being sufficiently tough on a particular banking institution, thus reducing the scope of the principal-agent problem.

Argentina has implemented a subordinated debt requirement in its BASIC program, although without an interest rate cap, which took effect on January 1998. As reported in Calomiris (1997), initially about half of the banks have been able to comply with this requirement. Interestingly, as expected, it is the weakest banks that have had trouble issuing subordinated debt. Thus, the subordinated debt requirement looks like it will have the intended effect of promoting discipline on the banks. However, it still remains to be seen how the Argentinean authorities will respond to the fact that many banks are not in compliance with this regulation. Thus it is too early to tell how successful the subordinated debt requirement will be.

\section{7) Limiting Too-Big-To-Fail}

Because the failure of a very large bank makes it more likely that a major, systemic financial disruption will occur, bank supervisors are naturally reluctant to allow a big bank to fail and cause losses to depositors. The result is that most countries either explicitly or implicitly have a too-big-to-fail policy in which all depositors at a big bank, both insured and uninsured are fully protected if the bank fails. As we have seen, the problem with the too-big-to-fail policy is that it reduces market discipline on big banks and thus increases their moral hazard incentives to take on excessive risk. How can bank supervisors deal with the quandary of not wanting to allow a large bank failure to destabilize the financial system, while keeping the moral hazard problem created by too-big-to-fail under control?

One proposal outlined in Mishkin (1999a) is for the supervisory agencies to announce that 
there is a strong presumption that when there is a bank failure, uninsured depositors would not be fully protected unless this is the cheapest way to resolve the failure. It is important to recognize that although large banking institutions may be too big to liquidate, they can be closed with losses imposed on uninsured creditors. Indeed this is exactly what FDICIA suggests should be done by specifying that, except under very unusual circumstances when a bank failure poses "serious adverse effects on economic conditions or financial stability", a least-cost resolution procedure will be used to close down the bank. Ambiguity is created about the use of this systemic-risk exception to the least-cost-resolution rule because to invoke it requires a two-thirds majority of both the Board of Governors of the Federal Reserve System and the directors of the FDIC, as well as the approval of the secretary of the Treasury.

An important concern is that the systemic-risk exception to least-cost resolution will always be invoked when the failing bank is large enough because the Fed, the FDIC and the secretary of the Treasury will be afraid to impose costs on depositors and other creditors when a potential financial crisis is looming. Thus too-big-to-fail will still be alive, with all the negative consequences for moral-hazard risk-taking by the largest institutions. One way to cope with this problem is for the authorities to announce that although they are concerned about systemic risk possibilities, there will be a strong presumption that the first large bank to fail will not be treated as too-big-to-fail and costs will be imposed on uninsured depositors and creditors when the bank is closed. Rather than bail out the uninsured creditors at the initial large bank that fails, the authorities will stand ready to extend the safety net to the rest of the banking system if they perceive that there is a serious systemic risk problem.

The advantage of announcing such a stance is that it creates constructive ambiguity for the large banks because their uninsured depositors and creditors now have to worry that if this bank is the first one to fail, they will not be bailed out. (The phrase "constructive ambiguity" may have a somewhat negative connotation because it seems to imply advocacy of randomness in the supervision process. The constructive ambiguity advocated here is closer to a contingent rule, but one in which some judgement needs to be applied by supervisors.) As a result these depositors and creditors will now have an incentive to withdraw their funds if they worry about the soundness of the bank, even if it is very large, and this will alter the incentives of the bank away from taking on 
too much risk. Clearly, moral hazard still remains in the system because the authorities stand ready to extend the safety net to the rest of the system after the initial large institution fails if its failure creates the potential for a banking crisis. However, the extent of moral hazard is greatly reduced by the use of this form of constructive ambiguity. Furthermore, the cost of this remaining moral hazard must be balanced against the benefits of preventing a banking crisis if the initial bank failure is likely to snowball into a systemic crisis.

One potential criticism of a presumption towards allowing the first large bank to fail is that there is a substantial risk of contagion through the payments system. ${ }^{28}$ The payments system relies on substantial extensions of intra-day, overnight and longer-term credit between banks. Failure of a large bank or one that is intimately involved in the large-dollar payments system could then lead to a systemic shock that could cause the payments system to freeze up or, at a minimum, lead to substantial losses at other banks. Thus attention needs to be paid to reduction of potential payment system and contagion problems.

Indeed, the FDICIA legislation of 1991 has done exactly this by taking important steps to deal with these problems through several provisions. FDICIA directed the Board of Governors of the Federal Reserve to develop a regulation which would limit inter-bank credit exposure, and the Board of Governors responded with Regulation F, which restricts the inter-day exposure to a not adequately capitalized correspondent to less than $25 \%$ of the bank's capital. To prevent a systemic liquidity problem from developing because other financial institutions might not have immediate access to their funds at a failed bank, FDICIA also authorizes the FDIC to make a final settlement with creditors when it assumes receivership of a failed bank. The settlement rate is based on the FDIC's average recovery experience. In addition, FDICIA explicitly recognizes contractual netting

\footnotetext{
${ }^{28}$ Another potential criticism of a presumption that only the first large bank to fail will impose costs on uninsured depositors and creditors is that creditors have incentives to pump capital into a failing institution to prop it up just long enough so that it will not be the first one to fail. There are several reasons to discount this criticism. First is that the free-rider problem strongly mitigates the incentive for creditors to prop up the bank: each creditor individually is quite happy to let the other creditors pump funds into the bank in order to delay the failure, and so the incentive of creditors to prop up the bank is greatly weakened. Second, is that constructive ambiguity does not guarantee that delaying the failure of the bank will do any good. If the regulatory authorities decide that failure of a second bank does not present the financial system with systemic risk, they may not decide to protect the creditors. Thus the incentive for creditors to prop up the bank temporarily will be further weakened.
} 
agreements and holds them legally binding, thereby reducing short-term credit exposure and making the clean up after a bank failure substantially easier.

Not only do these FDICIA provisions to limit inter-bank risk make it more likely that a large bank failure will not produce a systemic problem, but they also improve the incentives for the regulatory agencies to allow the first large bank to fail because the failure has less potential to do damage to the banking system. Thus, provisions of this type increase the credibility of the presumption that the first big bank will be allowed to fail and incur costs on the depositors and creditors, an essential feature of constructive ambiguity.

\section{8) Entry of Foreign Banks}

Many countries have restrictions on the entry of foreign banks. Although often viewed as a threat, entry of foreign banks is in reality an opportunity to strengthen the banking system. In all but a few large countries, domestic banks are unable to diversify because their lending is concentrated in the home country. In contrast, foreign banks have more diversified portfolios and also usually have access to sources of funds from all over the world through their parent company. This diversification means that these foreign banks are exposed to less risk and are less affected by negative shocks to the home country's economy. Because many emerging market countries are more volatile than industrialized countries, having a large foreign component to the banking sector is especially valuable because it helps insulate the banking system from domestic shocks. Encouraging entry of foreign banks is thus likely to lead to a banking and financial system that is substantially less fragile and far less prone to crisis.

Another reason for encouraging entry of foreign banks is that this can encourage adoption of best practice in the banking industry. Foreign banks come with expertise in areas like risk management. As mentioned earlier, when bank examiners in a country see better practices in risk management, they can spread these practices throughout their country's banking system by downgrading banks who do not adopt these practices. Having foreign banks to demonstrate the latest risk management techniques can thus lead to improved control of risk in the home country's banking system. Clearly, there are also benefits from the increased competition that foreign bank entry brings to the banking industry in the home country. Entry of foreign banks will lead to 
improved management techniques and a more efficient banking system.

During the restructuring process, the Korean government has been pursuing the policy of encouraging entry of foreign banks precisely based on the above reasoning. All the regulatory rigidities have been streamlined for foreign entry, and as long as foreign banks are able to prove soundness of the management and funding resources, they can enter the banking industry. In addition, the strict bank ownership regulations currently applied to domestic residents have been considerably allowed for foreign institutions in case they want to own major shares of domestic banks. The two largest nationalized commercial banks - the Korea First Bank and Seoul Bank are currently in a selling-off procedure and negotiations are proceeding with New Bridge Associates of GE Capital and HSBC, respectively. However, it is too early to forecast the final outcome because uncertainty remains on the quality of existing bank assets. Until the uncertainty is successfully resolved regarding the true status of bank capital and asset quality, reaching an agreement on the sales terms and prices would be inherently difficult.

\section{Monetary Policy Strategy}

Price stability is a worth goal in its own right. Not only do public opinion surveys indicate that the public is very hostile to inflation, but there is also mounting evidence from econometric studies that inflation is harmful to the economy. ${ }^{29}$ The asymmetric information analysis of the Korean financial crisis here provides additional reasons why the pursuit of price stability is so important for Korea. Achieving price stability is a necessary condition for having a sound currency and with a sound currency, it is far easier for banks, non-financial firms and the government to raise capital with debt denominated in domestic currency. As we have seen, having debt denominated in domestic currency makes the financial system less fragile because currency depreciation no longer causes a deterioration in balance sheets that can trigger a financial crisis.

The recognition that price stability should be the primary goal of monetary policy in Korea

\footnotetext{
${ }^{29}$ Inflation, particularly at high levels, is found to be negatively associated with growth. At lower levels, inflation is found to lower the level of economic activity, although not necessarily the growth rate. See the survey in Anderson and Gruen (1995) and Fischer (1993), one of the most cited papers in this literature.
} 
has resulted in the revised Bank of Korea Act which stipulates that price stability should be the primary goal of monetary policy. Although we have seen that the pursuit of price stability can enhance financial stability and is thus desirable, some methods of pursuing price stability can unfortunately promote financial instability. One method to achieve price stability, which was used by Korea, was to partially peg the value of its currency with a moving band to currencies of other large, low-inflation countries, with frequent interventions in the foreign exchange market to stabilize the value of the won.

Although adhering to a pegged exchange rate regime can be a successful strategy for controlling inflation, the asymmetric information framework in this paper illustrates how dangerous this strategy can be for an emerging market country with a large amount of foreign-denominated debt. Under a pegged exchange-rate regime, when a successful speculative attack occurs, the decline in the value of the domestic currency is usually much larger, more rapid and more unanticipated than when a depreciation occurs under a floating exchange-rate regime. The damage to balance sheets after the Korean devaluation was an important factor in producing its financial crisis.

Another potential danger from an exchange-rate peg is that by providing a more stable value of the currency, it might lower risk for foreign investors and thus encourage capital inflows. Although these capital inflows might be channeled into productive investments and thus stimulate growth, they can help promote excessive lending and increased vulnerability of their financial system. ${ }^{30}$ Furthermore, if the financial supervisory process is weak, as it was in Korea, the government safety net for financial institutions creates incentives for them to take on risk with the likely outcome of substantial loan losses and a deterioration of bank balance sheets, which culminates in a possible financial crisis.

A flexible exchange rate regime, with only infrequent foreign exchange market interventions, has the advantage that movements in the exchange rate are much less nonlinear than in a pegged exchange rate regime. Indeed, the daily fluctuations in the exchange rate in a flexible exchange rate regime have the advantage of making clear to private firms, banks, and governments that there is substantial risk involved in issuing liabilities denominated in foreign currencies. 
Furthermore, a depreciation of the exchange rate may provide an early warning signal to policymakers that their policies may have to be adjusted in order to limit the potential for a financial crisis.

The conclusion is that a partially pegged, exchange rate regime probably increased financial instability in Korea, and it is a poor strategy for Korean monetary policy. This immediately raises the question what other strategy can be used by Korea to control inflation?

A basic strategy for inflation control in Korea would have two basic components. First, the central bank requires sufficient independence so that it can pursue long-run objectives such as a price stability goal. Politicians in both industrialized and emerging market countries are likely to be shortsighted because they are driven by the need to win their next election. With their focus on the upcoming election, they are unlikely to focus on long-run objectives, such as promoting a stable price level. Instead, they will tend to seek short-run objectives, like low unemployment and low interest rates, even if the short-run objectives may have undesirable long-run consequences. If the central bank is controlled by the government, then it is likely to accede to these political demands, resulting in high inflation and low credibility for the central bank. Only with a grant of independence, can the central bank be sufficiently insulated from short-run political pressures so that it can focus on the long-run goal of inflation control. Recent evidence seems to support the conjecture that macroeconomic performance is improved when central banks are more independent. When central banks are ranked from least legally independent to most legally independent, the inflation performance is found to be the best for countries with the most independent central banks. 3132

The revised Bank of Korea Act passed in December 1997 goes a long way toward complying with the first component of a successful strategy for inflation control. ${ }^{33}$ The Bank's

\footnotetext{
${ }^{30}$ See Calvo, Leiderman and Reinhart (1994).

${ }^{31}$ See Alesina and Summers (1993), Cukierman (1992), and Fischer (1994) among others.

${ }^{32}$ However, there is some question as to whether causality runs from central bank independence to low inflation, or rather, whether a third factor is involved such as the general public's preferences for low inflation that create both central bank independence and low inflation (see Posen (1995)).

${ }^{33}$ See Bank of Korea (1998).
} 
independence has been increased by replacing the Minister of Finance and Economy as the chairman of the monetary board, which sets monetary policy, with the Governor of the Bank of Korea. Furthermore, the monetary board members are no longer appointed by the Ministry of Finance and Economy and can no longer be forced out of office before the expiration of their four year terms.

The second component of a successful strategy for inflation control is an explicit nominal anchor. An explicit nominal anchor helps to establish credibility for monetary policy and anchor inflation expectations, while it also helps to avoid the time-inconsistency problem described by Kydland and Prescott (1977), Calvo (1978) and Barro and Gordon (1983). The time-inconsistency problem arises because there are incentives for a policymaker to pursue discretionary policy to achieve short-run objectives, such as higher growth and employment, even though the result is poor long-run outcomes - high inflation. It is true that countries like the United States have often been able to conduct successful monetary policy without an explicit nominal anchor, but it is far more imperative to have an explicit nominal anchor in Korea because the Bank of Korea does not have the credibility of an institution like the Federal Reserve.

There are two basic alternatives to an exchange-rate peg for an explicit nominal anchor: monetary targets and inflation targets. Although monetary targets have been used successfully in some countries, particularly Germany, they may not be nearly as effective in the emerging market country context. Because of velocity shocks, the relationship between monetary aggregates and inflation has not been very tight, even in Germany. ${ }^{34}$ Thus hitting the monetary target will not always produce the desired inflation outcome and may not be a sufficiently good signal about the appropriate stance of monetary policy. Because of instabilities in the money-inflation relationship, no monetary targeter has strictly adhered to their targets: indeed, even the Germans miss their monetary target range on the order of 50 percent of the time. This was not a serious problem in the German context because of the high credibility of the German central bank, which was able to explain away the deviations from the target and yet not lose the public's belief in its commitment to price stability. Because the credibility of the central bank in Korea is much less than that of the Bundesbank, this strategy is unlikely to be nearly as successful in these countries.

\footnotetext{
${ }^{34}$ See Estrella and Mishkin (1997), for example.
} 
The other alternative nominal anchor for Korea would be an inflation target. Inflation targeting not only involves the public announcement of medium-term numerical targets for inflation with an institutional commitment by the monetary authorities to achieve these targets, but also includes increased communication with the public and the markets about the plans and objectives of monetary policymakers and increased accountability of the central bank for obtaining its inflation objectives. $^{35}$ As is outlined in Bernanke and Mishkin (1997), Mishkin and Posen (1997), Mishkin (1999b) and in our forthcoming book, Bernanke, Laubach, Mishkin and Posen (1999), the primary advantage of inflation targeting is its transparency to the public. Like an exchange-rate peg, it is readily understood by the public, but, even more directly than the others, it makes clear the commitment to price stability. Inflation targeting keeps the goal of price stability in the public's eye, thus making the central bank more accountable for keeping inflation low which helps counter the time-inconsistency problem.

In contrast to the exchange rate target, inflation targets enable monetary policy to focus on domestic considerations and to respond to shocks to the economy. Finally, inflation targets have the advantage that velocity shocks are largely irrelevant because the monetary policy strategy no longer requires a stable money-inflation relationship. Indeed, an inflation target allows the monetary authorities to use all available information, and not just one variable, to determine the best settings for monetary policy.

One criticism of inflation targets is that in contrast to exchange rates and monetary aggregates, inflation is not easily controlled by the monetary authorities. This can be a particularly severe problem for an emerging market country that is trying to bring down inflation from a previously high level and so is more likely to experience large inflation forecast errors. However, Korea is not in this situation. It currently is experiencing a very low inflation rate and as indicated in Table 1 has had inflation rates in the single digit range for many years. In addition, Hoffmaister (1999) has shown that the ability of the Korean monetary authorities to control and forecast inflation is sufficient for them to successfully pursue an inflation targeting strategy.

Another criticism of inflation targets is that a sole focus on inflation may lead to large

\footnotetext{
${ }^{35}$ Other detailed analyses of experiences with inflation targeting can be found in Goodhart and Vinals (1994), Leiderman and Svensson (1995), Haldane (1995) and McCallum (1996).
} 
adverse effects on output. Although this could be a problem if the inflation targeting implied that monetary authorities must try to reduce inflation very rapidly without concern for output fluctuations, as pointed out in Mishkin and Posen (1997) and Bernanke, Laubach, Mishkin and Posen (1999), this is not the way inflation targeting has been conducted in practice in the industrialized countries. All inflation-targeting central banks have left themselves considerable scope to respond to output growth and fluctuations. Furthermore, inflation targeting can actually help minimize output fluctuations. This is because inflation targeting provides not only a ceiling for the inflation rate, but also a floor. Inflation targeting can therefore act to attenuate the effects of negative, as well as positive, shocks to aggregate demand. Indeed, this benefit of inflation targeting has been emphasized by the Canadian monetary authorities.

Inflation targeting in Korea would be very consistent with the revised Bank of Korea Act which has taken effect in 1998. Besides increasing the independence of the central bank, this act stipulates that the Bank of Korea should set a price stability target in consultation with the government and to outline a plan to achieve this target. The Bank of Korea is obligated to publicly announce this plan, publish minutes of the monetary policy board meetings and submit a detailed report on monetary policy to the National Assembly at least once a year. Taking the further step of formally adopting an inflation targeting strategy would thus be relatively easy in Korea and would not only promote price stability in Korea, but help to avoid financial instability in the future. 


\section{References}

Alesina, A., and L. H. Summers (1993), "Central Bank Independence and Macroeconomic Performance: Some Comparative Evidence," Journal of Money, Credit, and Banking, Vol. 25, 151-62.

Anderson, P., and D. Gruen (1995), "Macroeconomic Policies and Growth," in Palle Anderson, Jacqui Dwyer and David Gruen, eds., Productivity and Growth, Reserve Bank of Australia: Sydney, 279-319.

Bank of Korea, (1998), "The Main Points of Reshaping the Central Banking and Financial Supervision System in Korea," Press Release, Research Department, the Bank of Korea, January.

Barro, R. J., and D. B. Gordon (1983), “A Positive Theory of Monetary Policy in a Natural Rate Model," Journal of Political Economy, Vol. 91, 589-610.

Berger, A. N., and G. Udell (1994), "Do Risk-Based Capital Requirements Allocate Bank Credit and Cause a 'Credit Crunch' in the United States?" Journal of Money, Credit and Banking, Vol. 26, 585-628.

Bernanke, B. S. (1983), "Nonmonetary Effects of the Financial Crisis in the Propagation of the Great Depression," American Economic Review, Vol. 73, 257-76.

Bernanke, B. S., and M. Gertler (1989), "Agency Costs, Collateral, and Business Fluctuations," American Economic Review, Vol. 79, 14-31.

Bernanke, B. S. and M. Gertler (1995), "Inside the Black Box: The Credit Channel of Monetary Policy Transmission," Journal of Economic Perspectives, 27-48.

Bernanke, B. S. and C. S. Lown (1991), "The Credit Crunch," Brookings Papers on Economic Activity, Vol. 2, pp. 205-39, Washington D. C.

Bernanke, B. S. and F. S. Mishkin (1997), "Inflation Targeting: A New Framework for Monetary Policy?" Journal of Economic Perspectives, Vol 11, 2, 97-116.

Bernanke, B. S., Laubach, T., Mishkin, F. S. and A. Posen (1999), Inflation Targeting: Lessons from International Experience, Princeton: Princeton University Press. 
Banco Central de la Republica Argentina (1997), "Main Features of the Regulatory Framework of the Argentine Financial System," mimeo, April.

Calomiris, C. W. (1997), The Postmodern Bank Safety Net: Lessons from Developed and Developing Countries, AEI Press: Washington, D.C.

Calomiris, C. W. and R. G. Hubbard (1990), "Firm Heterogeneity, Internal Finance, and `Credit Rationing"', Economic Journal, Vol. 100, 90-104.

Calvo, G. A. (1978), "On the Time Consistency of Optimal Policy in the Monetary Economy," Econometrica, Vol. 46, 1411-28.

Calvo, G. A., Leiderman, L. and C. M. Reinhart (1994), "The Capital Inflows Problem: Concepts and Issues," Contemporary Economic Policy, Vol. 12, 54-66, July.

Cecchetti, S. G. (1995), "Distinguishing Theories of the Monetary Transmission Mechanism," Federal Reserve Bank of St. Louis, Review, Vol. 77, 83-97, May/June.

Cho, D. C. (1999), "Recovering from the Crisis: Where the Korean Economy Stands?" mimeo, Korea Development Institute, July.

Cohen, D. (1992), “The Debt Crisis: a Postmortem," NBER Macroeconomics Annual, Olivier Blanchard and Stanley Fischer, eds, Cambridge: MIT Press.

Corsetti, G., Pesenti, P. and N. Roubini (1998), "What Caused the Asian Currency and Financial Crisis?” NBER Working Paper, March.

Cukierman, A. (1992), Central Bank Strategy, Credibility, and Independence: Theory and Evidence, Cambridge, Massachusetts: MIT Press.

Estrella, A. and F. S. Mishkin (1997), "Is There a Role for Monetary Aggregates in Conduct of Monetary Policy." Journal of Monetary Economics, Vol. 40, No. 2, 279-304, October.

Federal Reserve Bank of New York, (1993). "The Role of the Credit Slowdown in the Recent Recession," Federal Reserve Bank of New York Quarterly Review, Vol. 18, No. 1, Spring.

Fischer, S. (1993), "The Role of Macroeconomic Factors in Growth," Journal of Monetary Economics, Vol. 32, 485-512.

Fischer, S. (1994), "Modern Central Banking," in Forest Capie, Charles Goodhart, Stanley Fischer 
and Norbert Schnadt, eds. The Future of Central Banking: The Tercentenary Symposium of the Bank of England, Cambridge, England and New York: Cambridge University Press, 262-308.

Frankel, J. and A. Rose (1996), "Currency Crashes in Emerging Markets: Empirical Indicators," CEPR discussion paper, No. 1349.

Goldstein, M. (1996), "Presumptive Indicators/Early Warning Signals of Vulnerability to Financial Crises in Emerging-Market Economies," mimeo, Institute for International Economics.

Goldstein, M. (1998), “The Asian Financial Crisis,” Institute for International Economics mimeo, Washington D.C.

Greenwald, B. and J. E. Stiglitz (1988), "Information, Finance Constraints, and Business Fluctuations", in Kahn, M., and S. C. Tsiang, eds, Oxford University Press, Oxford.

Goodhart, C. and J. Vinals (1994), "Strategy and Tactics of Monetary Policy: Examples from Europe and the Antipodes," Jeffrey Fuhrer, ed., Goals, Guidelines, and Constraints Facing Monetary Policymakers, Federal Reserve Bank of Boston.

Hahm, J. H. and J. K. Yoo (1999), "Foreign Exchange Exposures of Korean Financial Institutions in the 1990s" (in Korean), KDI Journal of Economic Policy, Vol. 21, No. 2, forthcoming.

Haldane, A. G. (1995), Targeting Inflation, Bank of England: London.

Hancock, D., Laing, A. J. and J. A. Wilcox (1995), "Bank Capital Shocks: Dynamic Effects on Securities, Loans and Capital," Journal of Banking and Finance, Vol. 19, No. 3-4, 661-77.

Hoffmaister, A. W. (1999), "Inflation Targeting in Korea: An Empirical Investigation," IMF Working Paper WP/99/7, January.

Hubbard, R. G. (1995), "Is There a "Credit Channel" for Monetary Policy?" Federal Reserve Bank of St. Louis Review, Vol. 77, 63-74, May/June.

Joh, S. W. (1999), "The Korean Corporate Sector: Crisis and Reform," Korea Development Institute mimeo, August.

Kaminsky, G. L. and C. M. Reinhart (1996), "The Twin Crises: The Causes of Banking and Balance-of-Payments Problems," Board of Governors of the Federal Reserve System, 
International Finance Discussion Papers No. 544, March.

Kashyap, A. K., Stein, J. C. and D. W. Wilcox (1993), "Monetary Policy and Credit Conditions: Evidence from the Composition of External Finance," American Economic Review, Vol. 83, No. 1, 78-98.

Kim, J. K., Hahn, J. H., Joh, S. W., and D. S. Kim (1998), "Corporate Distress in Korea and Policy Implication,” (in Korean), KDI Research Report 98-20.

Kydland, F. E., and E. C. Prescott (1977), "Rules Rather Than Discretion: The Inconsistency of Optimal Plans," Journal of Political Economy, Vol. 85, 473-91.

Leiderman, L. and L. E. O. Svensson (1995), Inflation Targets, Centre for Economic Policy Research, London.

McCallum, B. T. (1996), "Inflation Targeting in Canada, New Zealand, Sweden, the United Kingdom, and in General," NBER Working Paper no. 5597, May.

McKinnon, R. and H. Pill (1996), "Credible Liberalizations and International Capital Flows: the Overborrowing Syndrome," in T. Ito and A. O. Krueger, eds, Financial Deregulation and Integration in East Asia, Chicago University Press.

Milesi-Ferretti, M. and A. Razin (1996), "Current Account Sustainability: Selected East Asian and Latin American Experiences," NBER working paper, No. 5791.

Mishkin, F. S. (1992) "An Evaluation of the Treasury Plan for Banking Reform," Journal of Economic Perspectives, Vol. 6, No. 1, 133-53, Winter.

Mishkin, F. S. (1996a), "Understanding Financial Crises: A Developing Country Perspective," in: Bruno, M. and B. Pleskovic, Eds, Annual World Bank Conference on Development Economics 1996, World Bank, Washington D.C., 29-62.

Mishkin, F. S. (1996b), "The Channels of Monetary Transmission: Lessons for Monetary Policy," Banque De France Bulletin Digest, No. 27, 33-44.

Mishkin, F. S. (1997a), "The Causes and Propagation of Financial Instability: Lessons for Policymakers," in: Hakkio, C. Ed., Maintaining Financial Stability in a Global Economy, Federal Reserve Bank of Kansas City, Kansas City, 55-96.

Mishkin, F. S. (1997b), "Evaluating FDICIA," in George Kaufman, ed., FDICIA: Bank Reform 
Five Years Later and Five Years Ahead, Greenwich, Conn.: JAI Press, 17-33.

Mishkin, F. S. (1998), The Economics of Money, Banking and Financial Markets, 5th Edition Reading, Mass: Addison Wesley Longman.

Mishkin, F. S. (1999a), "Financial Consolidation: Dangers and Opportunities" Journal of Banking and Finance, Vol. 23, Nos. 2-4, 675-91, February.

Mishkin, F. S. (1999b), "International Experiences with Different Monetary Policy Regimes," Journal of Monetary Economics, Vol. 43, No. 3, 579-606, June.

Mishkin, F. S. (2000), "Global Financial Instability: Framework, Events, Issues," Journal of Economic Perspectives, forthcoming, Winter.

Mishkin, F. S. and A. S. Posen (1997), "Inflation Targeting: Lessons from Four Countries," Federal Reserve Bank of New York, Economic Policy Review, No. 3, 9-110, August.

Peek, J. and E. S. Rosengren (1995), "Bank Regulation and the Credit Crunch," Journal of Banking and Finance, Vol. 19, Nos. 2-4, 679:92.

Posen, A. S. (1995), “Central Bank Independence and Disinflationary Credibility? A Missing Link?" Federal Reserve Bank of New York Staff Reports, No. 1, May.

Shin, I. S. (1998), "A Thought on the Triggering Mechanism of Korean Currency Crisis," (in Korean), KDI Journal of Economic Policy, Vol. 20, Nos. 3-4, 3-55.

Shin, I. S. and J. H. Hahm (1998), “The Korean Crisis: Causes and Resolution,” KDI Working Paper, No. 9805, July.

Sprong, K. (1994), Banking Regulation, Federal Reserve Bank of Kansas City: Kansas City, Mo.

Stiglitz, J. and A. Weiss (1981), "Credit Rationing in Markets with Imperfect Information," American Economic Review, Vol. 71, 393-410. 
$<$ Table 1> Macroeconomic Fundamentals

\begin{tabular}{|l|c|c|c|c|c|c|c|c|}
\hline & 1991 & 1992 & 1993 & 1994 & 1995 & 1996 & 1997 & 1998 \\
\hline $\begin{array}{l}\text { Fiscal Surplus } \\
\text { GDP / }\end{array}$ & -1.9 & -0.7 & 0.3 & 0.5 & 0.4 & 0.3 & -1.5 & -4.2 \\
\hline $\begin{array}{l}\text { Current Acct / GDP } \\
\text { Real Effective } \\
\text { Exchange Rate }\end{array}$ & -2.82 & -1.25 & 0.29 & -0.96 & -1.74 & -4.42 & -1.71 & 12.46 \\
\hline CPI Inflation & 93.5 & 98.8 & 100.9 & 98.3 & 98.0 & 96.0 & 104.6 & 131.1 \\
\hline Real GDP Growth & 9.3 & 6.3 & 4.8 & 6.2 & 4.5 & 4.9 & 4.5 & 7.5 \\
\hline Gross Savings Ratio & 9.2 & 5.4 & 5.5 & 8.3 & 8.9 & 6.8 & 5.0 & -5.8 \\
\hline
\end{tabular}

Notes: 1) Consolidated public sector.

2) Trade volume weighted, numbers below 100 means overvaluation.

Source: National Statistical Office, Bank of Korea, Ministry of Finance and Economy, and KDI.

$<$ Table 2> External Liabilities

(100 million US \$, \%)

\begin{tabular}{|c|c|c|c|c|c|c|c|}
\hline & 1992 & 1993 & 1994 & 1995 & 1996 & 1997 & 1998 \\
\hline $\begin{array}{l}\text { Gross External Liab. } \\
\text { (y-o-y growth rate) } \\
\text { - Financial Inst. } \\
\text { - Corporations }\end{array}$ & $\begin{array}{l}629.0 \\
436.0 \\
137.0 \\
\end{array}$ & $\begin{array}{l}670.0 \\
(6.52) \\
475.0 \\
156.0 \\
\end{array}$ & $\begin{array}{c}887.0 \\
(32.39) \\
651.0 \\
200.0 \\
\end{array}$ & $\begin{array}{c}1,197.0 \\
(34.95) \\
905.0 \\
261.0\end{array}$ & $\begin{array}{c}1,643.4 \\
(37.29) \\
1,165.3 \\
417.5 \\
\end{array}$ & $\begin{array}{c}1,580.6 \\
(-3.82) \\
896.0 \\
462.0\end{array}$ & $\begin{array}{c}1,493.5 \\
(-5.51) \\
719.0 \\
410.0\end{array}$ \\
\hline External Liab / GDP & 19.99 & 19.38 & 22.04 & 24.46 & 31.60 & 33.16 & 46.48 \\
\hline $\begin{array}{l}\text { Short-term Ext. Liab. } \\
\text { / Total Ext. Liab. }\end{array}$ & 58.82 & 60.15 & 65.84 & 65.75 & 56.58 & 40.00 & 20.64 \\
\hline $\begin{array}{l}\text { Short-term Ext. Liab. } \\
\text { / FX reserves }{ }^{3} \text { ) }\end{array}$ & 215.69 & 198.89 & 227.48 & 240.58 & 279.75 & 309.82 & 59.24 \\
\hline
\end{tabular}

Note: 1) External liabilities include external debts as defined by the IBRD, plus offshore borrowings of Korean banks and overseas borrowings of Korean banks' overseas branches.

2) Including foreign bank branches operating in Korea.

3) External liabilities and foreign exchange reserves are year end values.

Source: Ministry of Finance. 
<Table 3> Indicators of Bank Balance Sheets \& Asset Quality (average of 20 domestic commercial banks)

\begin{tabular}{|l|c|c|c|c|c|c|c|}
\hline & 1992 & 1993 & 1994 & 1995 & 1996 & 1997 & 1998 \\
\hline $\begin{array}{l}\text { Capital / Total Asset } \\
\text { Ratio }\end{array}$ & 6.77 & 6.13 & 5.68 & 4.78 & 4.26 & 2.99 & 2.82 \\
\hline BIS Capital Ratio $^{2)}$ & 11.18 & 11.0 & 10.62 & 9.33 & 9.14 & 7.04 & 8.23 \\
\hline $\begin{array}{l}\text { Non-performing } \\
\text { Loan Ratio }\end{array}$ & 7.1 & 7.4 & 5.8 & 5.2 & 4.1 & 6.0 & 7.4 \\
\hline
\end{tabular}

Notes: 1) Total bank assets include assets in trust account.

2) Allowance for valuation of securities and loan losses are reserved no less than $100 \%$ from 1998 .

3) The ratio of sum of estimated loss, doubtful, and substandard loans to total loans.

Source: Monthly Financial Statistics Bulletin, Feb. 1999, Financial Supervisory Service.

<Table 4> Indicators of Bank Management Performance (average of 20 domestic commercial banks, including trust accounts)

(year end value, $\%$, million won)

\begin{tabular}{|l|c|c|c|c|c|c|c|}
\hline & 1992 & 1993 & 1994 & 1995 & 1996 & 1997 & 1998 \\
\hline Return on Assets & 0.56 & 0.45 & 0.42 & 0.32 & 0.26 & -0.93 & -3.25 \\
(Foreign Banks) 1 ) & - & - & $(1.32)$ & $(1.17)$ & $(1.53)$ & $(3.89)$ & \\
\hline Return on Equity & 6.69 & 5.90 & 6.09 & 4.19 & 3.80 & -14.18 & -52.53 \\
(Foreign Banks) & - & - & $(10.96)$ & $(10.28)$ & $(12.51)$ & $(34.79)$ & \\
\hline Operating Income / & & & & & & & \\
Employee & 28.6 & 31.7 & 52.1 & 39.1 & 40.2 & 26.8 & \\
(Foreign Banks) & - & - & $(138.0)$ & $(146.0)$ & $(231.0)$ & $(819.0)$ & \\
\hline $\begin{array}{l}\text { Loan-Deposit Rate } \\
\text { Spread }\end{array}$ & 2.24 & 1.91 & 2.30 & 3.02 & 3.52 & 3.57 & \\
\hline
\end{tabular}

Note: 1) Foreign bank branches operating in Korea.

Source: Bank Management Statistics, 1999, Banking Supervisory Authority. 
<Table 5> Required Loan Loss Provision Adjusted Bank Capital (sum of 20 domestic commercial banks, banking accounts)

\begin{tabular}{|l|c|c|c|c|c|c|c|}
\hline & 1992 & 1993 & 1994 & 1995 & 1996 & 1997 & 1998 \\
\hline Book Bank Capital (A) & 13.39 & 14.28 & 16.76 & 18.91 & 20.11 & 18.14 & 15.96 \\
\hline $\begin{array}{l}\text { Allowances for Loan Losses } \\
\text { (B) }\end{array}$ & 1.66 & 2.00 & 2.36 & 3.16 & 3.42 & 5.61 & 10.27 \\
\hline $\begin{array}{l}\text { Actual / Required Loan Loss } \\
\text { Allowances }\end{array}$ & 0.50 & 0.50 & 0.61 & 0.72 & 0.86 & 0.95 & 1.00 \\
\hline $\begin{array}{l}\text { Additional Provisions } \\
\text { Required }^{3)}(\mathrm{D})\end{array}$ & 1.66 & 2.00 & 1.48 & 1.25 & 0.54 & 0.28 & 0.00 \\
\hline Adjusted Bank Capital $^{4)}(\mathrm{E})$ & 11.73 & 12.28 & 15.28 & 17.66 & 19.57 & 17.86 & 15.96 \\
\hline
\end{tabular}

Notes: 1) Ratio of actual loan loss allowances accumulated to loan loss allowances required assuming $100 \%$ provision.

2) We assumed 0.5 for 1992 and 93 as official data for the ratio is not available before 1994 .

3) Additional loan loss allowance that must be provisioned to raise it up to $100 \%$ of the required value. $(\mathrm{D}=\mathrm{B} / \mathrm{C}-\mathrm{B})$

4) Adjusted bank capital in each year under the assumption that additional reserves were provisioned to meet $100 \%$ of required loan loss allowances. $(\mathrm{E}=\mathrm{A}-\mathrm{D})$

Source: Bank Management Statistics, 1999, Banking Supervisory Authority, and authors' calculation. 
<Table 6> Latent Non-Performing Loans in Bank Balance Sheet

(20 domestic commercial banks, including trust account)

(year end value, \%, trillion won)

\begin{tabular}{|l|c|c|c|c|c|c|c|}
\hline & 1992 & 1993 & 1994 & 1995 & 1996 & 1997 & 1998 \\
\hline Bank Capital $^{1)}$ (A) & 11.73 & 12.28 & 15.28 & 17.66 & 19.57 & 17.86 & 15.96 \\
\hline $\begin{array}{l}\text { Total Financial Credit to the } \\
\text { Corporate Sector (B) }\end{array}$ & 311.4 & 365.7 & 438.0 & 519.5 & 630.2 & 788.9 & 777.9 \\
\hline $\begin{array}{l}\text { Ratio of Latent NPL to Total } \\
\text { Financial Credit) (C) }\end{array}$ & 0.22 & 0.26 & 0.19 & 0.17 & 0.22 & 0.26 & 0.32 \\
\hline $\begin{array}{l}\text { Ratio of Bank Credit to Total } \\
\text { Financial Credit (D) }\end{array}$ & 0.23 & 0.22 & 0.22 & 0.22 & 0.21 & 0.20 & 0.20 \\
\hline $\begin{array}{l}\text { Estimated Latent NPL in } \\
\text { Bank Balance Sheet }{ }^{3)}(\mathrm{E})\end{array}$ & 15.1 & 20.1 & 18.4 & 19.2 & 29.4 & 41.8 & 50.3 \\
\hline $\begin{array}{l}\text { Additional Reserve } \\
\text { Required }\end{array}$ & 1.51 & 2.01 & 1.84 & 1.92 & 2.94 & 4.18 & 5.03 \\
\hline Adjusted Bank Capital ${ }^{5)}(\mathrm{G})$ & 10.22 & 10.27 & 13.44 & 15.74 & 16.63 & 13.68 & 10.93 \\
\hline $\begin{array}{l}\text { Adjusted Bank Capital/ } \\
\text { Total Bank Assets }\end{array}$ (\%) & 5.17 & 4.41 & 4.55 & 3.98 & 3.52 & 2.26 & 1.93 \\
\hline
\end{tabular}

Notes: 1) The $100 \%$ loan loss provision adjusted bank capital computed in Table 5.

2) The ratio of potentially non-performing credit out of total corporate borrowings, where potentially non-performing credit is the borrowings of corporate firms whose interest coverage ratio (EBITDA/Interest Payment) is less than one.

3) $\mathrm{E}=\mathrm{B} \times \mathrm{C} \times \mathrm{D}$.

4) $\mathrm{F}=0.1 \times \mathrm{E}$, assuming on average $10 \%$ reserve requirement for the latent NPL.

5) $\mathrm{G}=\mathrm{A}-\mathrm{F}$.

6) Total bank assets include assets in trust account.

Source: Authors' calculation. 
$<$ Table 7> Indicators of Corporate Sector Profitability

(listed companies, excluding financial Institutions)

\begin{tabular}{|l|c|c|c|c|c|c|c|}
\hline & 1991 & 1992 & 1993 & 1994 & 1995 & 1996 & 1997 \\
\hline Return on Assets & 1.8 & 1.5 & 1.1 & 2.0 & 2.5 & 0.8 & -0.7 \\
\hline Return on Equity & 6.0 & 5.1 & 4.0 & 6.9 & 8.7 & 2.7 & -2.9 \\
\hline $\begin{array}{l}\text { Y-to-Y Operating } \\
\text { Income Growth Rate }\end{array}$ & 29.1 & 11.9 & 16.7 & 21.1 & 26.0 & -14.4 & 22.9 \\
\hline
\end{tabular}

Source: Monthly Financial Statistics Bulletin, 1999.2, Financial Supervisory Service.

$<$ Table 8> Return on Assets of 30 Largest Conglomerates

\begin{tabular}{|l|c|c|c|c|c|}
\hline & 1993 & 1994 & 1995 & 1996 & 1997 \\
\hline $1-5^{\text {th }}$ chaebols & 1.86 & 3.54 & 4.86 & 1.41 & 0.43 \\
\hline $6-10^{\text {th }}$ chaebols & 0.87 & 1.17 & 1.10 & -0.49 & -2.15 \\
\hline $11-30^{\text {th }}$ chaebols & -0.40 & -0.06 & -0.08 & 0.08 & -3.00 \\
\hline All 30 chaebols & 1.11 & 2.19 & 3.15 & 0.23 & -2.13 \\
\hline
\end{tabular}

Source: Simple averages of each chaebol's return on asset figures reported in Joh (1999). 
$<$ Table 9> Corporate Debt Balances by Source

(trillion won, \%)

\begin{tabular}{|c|c|c|c|c|c|c|c|c|}
\hline & Bank & Non-bank & $\begin{array}{c}\text { Corporate } \\
\text { Bond }\end{array}$ & CP & Foreign & $\begin{array}{c}\text { Account } \\
\text { Payable }\end{array}$ & Others & Total \\
\hline 1990 & 50.14 & 47.68 & 29.39 & 12.74 & 14.65 & 27.05 & 37.44 & 219.08 \\
& $(22.89)$ & $(21.76)$ & $(13.41)$ & $(5.82)$ & $(6.69)$ & $(12.35)$ & $(17.09)$ & $(100.0)$ \\
\hline 1991 & 62.23 & 61.86 & 43.45 & 10.53 & 18.02 & 32.11 & 43.33 & 271.54 \\
& $(22.92)$ & $(22.78)$ & $(16.00)$ & $(3.88)$ & $(6.64)$ & $(11.83)$ & $(15.96)$ & $(100.0)$ \\
\hline 1992 & 70.28 & 73.46 & 50.07 & 14.71 & 15.82 & 36.99 & 50.09 & 311.42 \\
& $(22.57)$ & $(23.59)$ & $(16.08)$ & $(4.72)$ & $(5.08)$ & $(11.88)$ & $(16.09)$ & $(100.0)$ \\
\hline 1993 & 79.01 & 85.35 & 59.52 & 23.73 & 16.99 & 42.83 & 58.23 & 365.66 \\
& $(21.61)$ & $(23.34)$ & $(16.28)$ & $(6.49)$ & $(4.65)$ & $(11.71)$ & $(15.92)$ & $(100.0)$ \\
\hline 1994 & 97.13 & 106.56 & 72.13 & 28.13 & 21.73 & 48.97 & 63.37 & 438.02 \\
& $(22.18)$ & $(24.33)$ & $(16.47)$ & $(6.42)$ & $(4.96)$ & $(11.18)$ & $(14.47)$ & $(100.0)$ \\
\hline 1995 & 112.37 & 123.51 & 87.48 & 44.23 & 28.81 & 53.93 & 69.13 & 519.46 \\
& $(21.63)$ & $(23.78)$ & $(16.84)$ & $(8.51)$ & $(5.55)$ & $(10.38)$ & $(13.31)$ & $(100.0)$ \\
\hline 1996 & 130.78 & 140.06 & 111.44 & 64.58 & 42.85 & 61.99 & 78.54 & 630.23 \\
& $(20.75)$ & $(22.22)$ & $(17.68)$ & $(10.25)$ & $(6.80)$ & $(9.84)$ & $(12.46)$ & $(100.0)$ \\
\hline 1997 & 161.12 & 174.74 & 138.98 & 69.05 & 79.52 & 74.60 & 90.96 & 788.96 \\
& $(20.42)$ & $(22.15)$ & $(17.62)$ & $(8.75)$ & $(10.08)$ & $(9.46)$ & $(11.53)$ & $(100.0)$ \\
\hline 1998 & 156.50 & 156.10 & 184.80 & 57.30 & 54.00 & 69.00 & 100.20 & 777.90 \\
& $(20.12)$ & $(20.07)$ & $(23.76)$ & $(7.37)$ & $(6.94)$ & $(8.87)$ & $(12.88)$ & $(100.0)$ \\
\hline
\end{tabular}

Source: Flow of Funds Accounts, various issues, Bank of Korea 
$<$ Table 10> Foreign Currency Denominated Debts in the Corporate Sector

(trillion won)

\begin{tabular}{|c|c|c|c|c|c|c|c|}
\hline & 1992 & 1993 & 1994 & 1995 & 1996 & 1997 & 1998 \\
\hline External Debt (A) & 15.82 & 16.99 & 21.73 & 28.81 & 42.85 & 79.52 & 54.00 \\
\hline External Asset (B) & 4.36 & 3.89 & 4.74 & 6.30 & 8.34 & 18.71 & 16.83 \\
\hline Net External Debt (C) & 11.46 & 13.09 & 16.99 & 22.51 & 34.51 & 60.26 & 37.12 \\
\hline $\begin{array}{l}\text { Foreign Currency } \\
\text { Loans from Domestic } \\
\text { Financial Inst. (D) }\end{array}$ & 14.73 & 14.45 & 18.50 & 23.18 & 29.81 & 49.92 & 44.47 \\
\hline $\begin{array}{l}\text { Deposits in Foreign } \\
\text { Currency (E) }\end{array}$ & 9.59 & 13.09 & 15.04 & 16.77 & 17.85 & 56.60 & 35.55 \\
\hline $\begin{array}{l}\text { Net domestic Foreign } \\
\text { Currency Debt }(\mathrm{F})\end{array}$ & 5.14 & 1.36 & 3.46 & 6.41 & 11.96 & -6.68 & 8.92 \\
\hline $\begin{array}{l}\text { Total Foreign Currency } \\
\text { Debt }(A+D)\end{array}$ & 30.55 & 31.44 & 40.23 & 51.99 & 72.66 & 129.44 & 98.47 \\
\hline Total Corp. Debt (G) & 311.42 & 365.66 & 438.02 & 519.46 & 630.23 & 788.96 & 777.90 \\
\hline $\begin{array}{l}\text { Net Foreign Currency } \\
\text { Debt relative to Total } \\
\text { Foreign Currency Debt } \\
((\mathrm{C}+\mathrm{F}) /(\mathrm{A}+\mathrm{D}))(\%)\end{array}$ & 54.34 & 45.96 & 50.83 & 55.63 & 63.96 & 41.39 & 46.76 \\
\hline $\begin{array}{l}\text { Share of Foreign } \\
\text { Currency Debt out of } \\
\text { Total Corporate Debt } \\
((A+D) / G)(\%)\end{array}$ & 9.81 & 8.60 & 9.18 & 10.01 & 11.53 & 16.41 & 12.66 \\
\hline
\end{tabular}

Note: 1) This amount includes foreign currency deposits of households and financial institutions, as well

as corporate firms. Unfortunately further breakdown according to deposit sources is not available. Hence, the net domestic foreign currency debt (F) is the minimum amount assuming that all of the foreign currency deposits were made by the corporate sector.

Source: Flow of Funds Account, Bank of Korea, and authors' calculation. 
$<$ Table 11> Official Foreign Exchange Reserves In the Crisis Episode

\begin{tabular}{|l|cccccccc|}
\hline & 96.12 .31 & 97.3 .31 & 6.30 & 9.30 & 10.31 & 11.30 & 12.31 & (billion U.S dollars) \\
\hline $\begin{array}{l}\text { Official Foreign } \\
\text { Reserves (A) }\end{array}$ & 33.2 & 29.1 & 33.3 & 30.4 & 30.5 & 24.4 & 20.4 & 23.5 \\
\hline $\begin{array}{l}\text { Overseas branch } \\
\text { Deposits (B) }\end{array}$ & 3.8 & 8.0 & 8.0 & 8.0 & 8.0 & 16.9 & 11.3 & 10.9 \\
\hline Others (C) & $\bullet$ & $\bullet$ & $\bullet$ & $\bullet$ & 0.2 & 0.2 & 0.2 & 0.2 \\
\hline A-(B+C) & 29.4 & 21.1 & 25.3 & 22.4 & 22.3 & 7.3 & 8.9 & 12.4 \\
\hline
\end{tabular}

Source: Bank of Korea

<Table 12> Financial Industry's Exposure to Exchange Rates

(1990:3 1999:4, monthly data)

Dependent Variable: Returns on each financial industry's stock price index

Regression A: $R_{\mathrm{t}} \bullet \beta_{0} \bullet \beta_{1} D E P_{\mathrm{t}} \bullet \varepsilon_{\mathrm{t}}$

\begin{tabular}{|c|c|c|c|c||}
\hline & Banks & Merchant Banks & Insurance & Security Firms \\
\hline \hline$\beta_{1}$ & $\begin{array}{c}-0.5288^{*} \\
(-1.70)\end{array}$ & $\begin{array}{c}-1.1722^{* * *} \\
(-3.88)\end{array}$ & $\begin{array}{c}-0.5920 \\
(-1.60)\end{array}$ & $\begin{array}{c}-1.3643^{* * * *} \\
(-2.95)\end{array}$ \\
\hline Adjusted $\mathrm{R}^{2} / \mathrm{DW}$ & $0.02 / 1.78$ & $0.12 / 2.35$ & $0.02 / 1.94$ & $0.07 / 1.58$ \\
\hline
\end{tabular}

Regression B: $R_{\mathrm{t}} \bullet \beta_{0} \bullet \beta_{1} R M K T_{\mathrm{t}} \bullet \beta_{2} D E P_{\mathrm{t}} \bullet \varepsilon_{\mathrm{t}}$

\begin{tabular}{|c|c|c|c|c||}
\hline & Banks & Merchant Banks & Insurance & Security Firms \\
\hline \hline$\beta 1$ & $0.8231^{* * *}$ & $0.7549^{* * *}$ & $1.2262^{* * *}$ & $1.5149^{* * *}$ \\
$(\mathrm{t}-\mathrm{value})$ & $(9.20)$ & $(8.38)$ & $(15.74)$ & $(15.05)$ \\
\hline$\beta 2$ & -0.2107 & $-0.8805^{* * *}$ & -0.1182 & $-0.7789^{* * *}$ \\
$(\mathrm{t}-\mathrm{value})$ & $(-0.89)$ & $(-3.70)$ & $(-0.57)$ & $(-2.93)$ \\
\hline Adjusted $\mathrm{R}^{2} / \mathrm{DW}$ & $0.45 / 2.34$ & $0.46 / 2.39$ & $0.70 / 2.10$ & $0.70 / 1.95$ \\
\hline
\end{tabular}


$<$ Table 13> Financing Conditions of SMEs

\begin{tabular}{|c|c|c|c|c|c|c|c|c|}
\hline & 1990 & 1991 & 1992 & 1993 & 1994 & 1995 & 1996 & 1997 \\
\hline $\begin{array}{l}\text { Borrowings during Year } \\
\text { (\% of Bank Loan) } \\
\text { (\% of Other Finan. Inst.) } \\
(\% \text { of Private Curb Loan) } \\
\text { (\% of Others) }\end{array}$ & $\begin{array}{c}9.8 \\
(75.0) \\
(16.9) \\
(2.3) \\
(5.8)\end{array}$ & $\begin{array}{l}11.7 \\
(75.1) \\
(15.9) \\
(2.3) \\
(6.7)\end{array}$ & $\begin{array}{l}11.3 \\
(75.1) \\
(16.0) \\
(2.3) \\
(6.6)\end{array}$ & $\begin{array}{c}14.9 \\
(77.5) \\
(14.2) \\
(2.1) \\
(6.2)\end{array}$ & $\begin{array}{c}18 \\
(78.3) \\
(13.6) \\
(2.0) \\
(6.1)\end{array}$ & $\begin{array}{c}20.1 \\
(77.9) \\
(13.7) \\
(2.0) \\
(6.4)\end{array}$ & $\begin{array}{c}22.0 \\
(78.6) \\
(13.3) \\
(2.1) \\
(6.0)\end{array}$ & $\begin{array}{l}21.0 \\
(73.7) \\
(10.5) \\
(6.3) \\
(9.5)\end{array}$ \\
\hline $\begin{array}{l}\text { Bank Loan during Year } \\
(\% \text { without Collateral) }\end{array}$ & $\begin{array}{c}7.4 \\
(18.5)\end{array}$ & $\begin{array}{c}8.8 \\
(19.1)\end{array}$ & $\begin{array}{c}8.5 \\
(19.0)\end{array}$ & $\begin{array}{l}11.5 \\
(20.4)\end{array}$ & $\begin{array}{c}14.1 \\
(21.5)\end{array}$ & $\begin{array}{l}15.7 \\
(21.9)\end{array}$ & $\begin{array}{l}17.3 \\
(20.0)\end{array}$ & $\begin{array}{l}15.5 \\
(8.3)\end{array}$ \\
\hline $\begin{array}{l}\text { Avg. Private Curb Loan } \\
\text { Monthly Interest Rate (\%) } \\
\text { (A: 5 9 employees) } \\
\text { (B: 200 299 employees) } \\
\text { (A-B) } \\
\text { Share of Loans with } \\
\text { Maturities less than } 2 \\
\text { Months (\%) }\end{array}$ & $\begin{array}{c}1.96 \\
\\
(2.05) \\
(1.82) \\
(0.23) \\
10.2\end{array}$ & $\begin{array}{c}2.03 \\
\\
(2.02) \\
(2.19) \\
(-0.17) \\
6.4\end{array}$ & $\begin{array}{c}1.92 \\
\\
(1.99) \\
(1.93) \\
(0.06) \\
4.7\end{array}$ & $\begin{array}{c}1.89 \\
(1.96) \\
(1.84) \\
(0.12) \\
10.2\end{array}$ & $\begin{array}{c}2.04 \\
\\
(2.02) \\
(1.40) \\
(0.62) \\
5.8\end{array}$ & $\begin{array}{c}2.00 \\
\\
(2.08) \\
(1.45) \\
(0.63) \\
7.1\end{array}$ & $\begin{array}{c}2.08 \\
(2.15) \\
(1.53) \\
(0.62) \\
7.2\end{array}$ & $\begin{array}{c}2.66 \\
\\
(2.32) \\
(1.33) \\
(0.99) \\
66.4\end{array}$ \\
\hline $\begin{array}{l}\text { No.1 Impediment in Corp. } \\
\text { Financial Management } \\
\text { (\%, External Financing) } \\
\text { (\%, Lagged Collection) } \\
\text { (\%, Decreasing Profits) } \\
\text { (\%, Rising Financing } \\
\text { Cost) }\end{array}$ & & & & $\begin{array}{l}(20.7) \\
(30.1) \\
(35.6) \\
(11.0)\end{array}$ & $\begin{array}{l}(16.5) \\
(31.2) \\
(34.5) \\
(12.4)\end{array}$ & $\begin{array}{l}(15.1) \\
(32.2) \\
(33.0) \\
(13.7)\end{array}$ & $\begin{array}{l}(17.1) \\
(34.5) \\
(25.7) \\
(14.1)\end{array}$ & $\begin{array}{l}(13.1) \\
(42.3) \\
(22.7) \\
(19.9)\end{array}$ \\
\hline
\end{tabular}

Source: Survey of Small and Medium Industries' Financial Standing, various issues, Kookmin Bank. 
<Table 14> Analysis of Real Bank Credit Growth

$(1990: 1 \bullet 1999: 2$, monthly data)

\begin{tabular}{|c|c|c|c|c|c|c|}
\hline \multirow[b]{2}{*}{$\begin{array}{l}\text { Explanatory } \\
\text { Variable }\end{array}$} & \multicolumn{3}{|c|}{$\begin{array}{l}\text { Dependent Variable: } \\
\text { Real Bank Private Credit Growth }\end{array}$} & \multicolumn{3}{|c|}{$\begin{array}{l}\text { Dependent Variable: } \\
\text { Real Bank Loan Growth }\end{array}$} \\
\hline & OLS & IV & $\begin{array}{l}\text { OLS with } \\
\text { Dummy }\end{array}$ & OLS & IV & $\begin{array}{l}\text { OLS with } \\
\text { Dummy }\end{array}$ \\
\hline $\begin{array}{l}\text { Growth in } \\
\text { Industrial } \\
\text { Production }\end{array}$ & $\begin{array}{l}0.3267^{* * *} \\
(5.10)\end{array}$ & $\begin{array}{l}0.4591^{* * *} \\
(3.19)\end{array}$ & $\begin{array}{l}0.1823^{* *} \\
(2.48)\end{array}$ & $\begin{array}{l}0.3067^{* * *} \\
(4.74)\end{array}$ & $\begin{array}{l}0.4548^{* * * *} \\
(2.94)\end{array}$ & $\begin{array}{l}0.1211^{*} \\
(1.78)\end{array}$ \\
\hline $\begin{array}{l}\text { Growth in } \\
\text { Real M2 }\end{array}$ & $\begin{array}{c}-0.5217^{* * *} \\
(-4.68)\end{array}$ & $\begin{array}{l}-0.4214^{* *} \\
(-2.60)\end{array}$ & $\begin{array}{c}-0.5440^{* * *} \\
(-4.43)\end{array}$ & $\begin{array}{c}-0.2604^{* * *} \\
(-2.31)\end{array}$ & $\begin{array}{c}-0.1490 \\
(-0.86)\end{array}$ & $\begin{array}{l}-0.3111^{* * *} \\
(-2.72)\end{array}$ \\
\hline $\begin{array}{l}\text { Real Interest Rate } \\
\text { (Corporate Bond Yield) }\end{array}$ & $\begin{array}{c}1.4100^{* * *} \\
(6.36)\end{array}$ & $\begin{array}{c}2.6520^{* * *} \\
(5.16)\end{array}$ & $\begin{array}{c}1.5697^{* * *} \\
(8.08)\end{array}$ & $\begin{array}{l}1.3374^{* * *} \\
(5.97)\end{array}$ & $\begin{array}{l}2.8537^{* * *} \\
(5.18)\end{array}$ & $\begin{array}{c}1.5380^{* * *} \\
(8.52)\end{array}$ \\
\hline \begin{tabular}{|l|} 
Dishonored Bill \\
Ratio
\end{tabular} & $\begin{array}{l}-3.7271^{*} \\
(-1.83)\end{array}$ & $\begin{array}{l}-5.0797 \\
(-1.06)\end{array}$ & $\begin{array}{c}18.0780^{* * *} \\
(4.63)\end{array}$ & \begin{tabular}{|c}
$-7.2644^{* * *}$ \\
$(-3.53)$
\end{tabular} & $\begin{array}{c}-9.6117^{*} \\
(-1.87)\end{array}$ & \begin{tabular}{|l}
$18.9144^{* * *}$ \\
$(5.21)$
\end{tabular} \\
\hline \begin{tabular}{|l|} 
Dummy \\
Dishonored Bill \\
Ratio
\end{tabular} & & & $\begin{array}{c}-23.6080^{* * *} \\
(-6.23)\end{array}$ & & & $\begin{array}{c}-28.3503^{* * *} \\
(-8.05)\end{array}$ \\
\hline $\begin{array}{l}\text { Growth in Real } \\
\text { Bank Capital }\end{array}$ & $\begin{array}{l}0.0973^{* * *} \\
(5.39)\end{array}$ & $\begin{array}{l}0.1054^{* * *} \\
(2.96)\end{array}$ & $\begin{array}{l}0.1113^{* * *} \\
(6.61)\end{array}$ & $\begin{array}{c}0.0612^{* * *} \\
(3.35)\end{array}$ & $\begin{array}{l}0.0355 \\
(0.94)\end{array}$ & $\begin{array}{l}0.0799^{* * *} \\
(5.10)\end{array}$ \\
\hline $\begin{array}{l}\text { Dummy } \bullet \\
\text { Growth in Real } \\
\text { Bank Capital }\end{array}$ & & & $\begin{array}{l}0.0066 \\
(0.07)\end{array}$ & & & $\begin{array}{l}-0.0228 \\
(-0.25)\end{array}$ \\
\hline Adjusted $\mathrm{R}^{2}$ & 0.60 & 0.42 & 0.71 & 0.52 & 0.23 & 0.71 \\
\hline DW & 0.52 & 0.69 & 0.75 & 0.46 & 0.61 & 0.89 \\
\hline
\end{tabular}

Notes: 1) ${ }^{* *}$ denotes the coefficient estimate is significant at $5 \%$ level, and ${ }^{* * *}$ denotes significant at $1 \%$ level (t-values are in the parenthesis).

2) Dummy stands for the financial crisis period (97:11 99:2).

3) Constant was included in all regressions but not reported to save space.

4) Instruments for instrumental variables regressions (IV) are constant and three lags of the following variables: industrial production growth, real M2 growth, dishonored bill ratio, real bank capital growth, and bank private credit to asset ratio. 


\section{<Table 15> Analysis of Bank Portfolio}

$(1990: 1 \bullet 1999: 2$, monthly data)

\begin{tabular}{|c|c|c|c|c|c|c|}
\hline \multirow[b]{2}{*}{$\begin{array}{l}\text { Explanatory } \\
\text { Variable }\end{array}$} & \multicolumn{3}{|c|}{$\begin{array}{l}\text { Dependent Variable: } \\
\text { Private Credit / Total Asset }\end{array}$} & \multicolumn{3}{|c|}{$\begin{array}{l}\text { Dependent Variable: } \\
\text { Loan / Private Credit }\end{array}$} \\
\hline & OLS & IV & $\begin{array}{l}\text { OLS with } \\
\text { Dummy }\end{array}$ & OLS & IV & $\begin{array}{l}\text { OLS with } \\
\text { Dummy }\end{array}$ \\
\hline $\begin{array}{l}\text { First Lag of } \\
\text { Dep. Variable }\end{array}$ & $\begin{array}{c}0.8629^{* * *} \\
(19.32)\end{array}$ & $\begin{array}{c}0.6061^{* * *} \\
(5.67)\end{array}$ & $\begin{array}{c}0.7643^{* * *} \\
(14.99)\end{array}$ & $\begin{array}{l}0.9753^{* * *} \\
(50.46)\end{array}$ & $\begin{array}{l}0.9798^{* * *} \\
(19.40)\end{array}$ & $\begin{array}{c}0.9745^{* * *} \\
(47.63)\end{array}$ \\
\hline $\begin{array}{l}\text { Growth in } \\
\text { Industrial } \\
\text { Production }\end{array}$ & $\begin{array}{l}0.0356 \\
(1.29)\end{array}$ & $\begin{array}{r}0.1302^{*} \\
(1.93)\end{array}$ & $\begin{array}{c}0.0418 \\
(1.33)\end{array}$ & $\begin{array}{c}-0.0207^{* * *} \\
(-2.93)\end{array}$ & $\begin{array}{c}-0.0148 \\
(-1.16)\end{array}$ & $\begin{array}{c}-0.0247^{* * *} \\
(-2.67)\end{array}$ \\
\hline $\begin{array}{l}\text { Growth in } \\
\text { Real M2 }\end{array}$ & $\begin{array}{l}-0.0653 \\
(-1.43)\end{array}$ & $\begin{array}{l}-0.1165 \\
(-1.61)\end{array}$ & $\begin{array}{l}-0.0688 \\
(-1.19)\end{array}$ & $\begin{array}{l}-0.0232^{* *} \\
(-1.96)\end{array}$ & $\begin{array}{c}-0.0306^{* *} \\
(-2.10)\end{array}$ & $\begin{array}{l}-0.0247 \\
(-1.55)\end{array}$ \\
\hline $\begin{array}{l}\text { Real Interest Rate } \\
(\text { Corporate Bond Yield) }\end{array}$ & $\begin{array}{l}0.0714 \\
(0.73)\end{array}$ & $\begin{array}{l}0.8827^{* *} \\
(2.47)\end{array}$ & $\begin{array}{l}0.2106^{* *} \\
(2.02)\end{array}$ & $\begin{array}{l}-0.0129 \\
(-0.55)\end{array}$ & $\begin{array}{l}-0.0418 \\
(-0.67)\end{array}$ & $\begin{array}{l}-0.0085 \\
(-0.34)\end{array}$ \\
\hline $\begin{array}{l}\text { Dishonored Bill } \\
\text { Ratio }\end{array}$ & $\begin{array}{l}-3.9266^{* * *} \\
(-4.73)\end{array}$ & $\begin{array}{c}-7.4078^{* * *} \\
(-2.92)\end{array}$ & $\begin{array}{l}1.8638 \\
(1.06)\end{array}$ & $\begin{array}{c}-0.9252^{* * *} \\
(-3.61)\end{array}$ & $\begin{array}{c}-0.5609 \\
(-0.65)\end{array}$ & $\begin{array}{c}-0.4029 \\
(-0.82)\end{array}$ \\
\hline $\begin{array}{l}\text { Dummy • } \\
\text { Dishonored Bill } \\
\text { Ratio }\end{array}$ & & & $\begin{array}{c}-6.9423^{* * *} \\
(-3.62)\end{array}$ & & & $\begin{array}{l}-0.5725 \\
(-1.24)\end{array}$ \\
\hline $\begin{array}{l}\text { Growth in Real } \\
\text { Bank Capital }\end{array}$ & $\begin{array}{l}0.0054 \\
(0.71)\end{array}$ & $\begin{array}{l}0.0071 \\
(0.47)\end{array}$ & $\begin{array}{l}0.0063 \\
(0.78)\end{array}$ & $\begin{array}{l}-0.0001 \\
(-0.01)\end{array}$ & $\begin{array}{c}-0.0019 \\
(-0.47)\end{array}$ & $\begin{array}{l}-0.0005 \\
(10.18)\end{array}$ \\
\hline $\begin{array}{l}\text { Dummy } \\
\text { Growth in Real } \\
\text { Bank Capital }\end{array}$ & & & $\begin{array}{l}0.0541 \\
(1.26)\end{array}$ & & & $\begin{array}{l}-0.0011 \\
(-0.09)\end{array}$ \\
\hline Adjusted $\mathrm{R}^{2}$ & 0.91 & 0.85 & 0.92 & 0.98 & 0.98 & 0.98 \\
\hline DW & 2.57 & 1.42 & 2.56 & 1.72 & 1.60 & 1.75 \\
\hline
\end{tabular}

Notes: 1$)^{* *}$ denotes the coefficient estimate is significant at $5 \%$ level, and ${ }^{* * *}$ denotes significant at $1 \%$ level (t-values are in the parenthesis).

2) Dummy stands for the financial crisis period (97:11 99:2).

3) Constant was included in all regressions but not reported to save space.

4) Instruments for instrumental variables regressions (IV) are constant and three lags of the following variables: industrial production growth, real M2 growth, dishonored bill ratio, real bank capital growth, and bank private credit to asset ratio. 


\section{<Table 16> Bank Credits and Economic Activity}

$(1990: 1 \bullet 1999: 2$, monthly data)

Dependent Variable: Growth in Industrial Production, OLS Estimations

\begin{tabular}{|c|c|c|c|}
\hline Explanatory Variable & (1) & (2) & (3) \\
\hline $\begin{array}{l}\text { First Lag of Industrial } \\
\text { Production Growth }\end{array}$ & $\begin{array}{c}0.5002^{* * *} \\
(5.57)\end{array}$ & $\begin{array}{c}0.4120^{* * *} \\
(4.50)\end{array}$ & $\begin{array}{l}0.3912^{* * * *} \\
(4.14)\end{array}$ \\
\hline Real M2 Growth & $\begin{array}{l}0.1277 \\
(0.79)\end{array}$ & $\begin{array}{c}0.1636 \\
(1.05)\end{array}$ & $\begin{array}{l}0.1965 \\
(1.23)\end{array}$ \\
\hline $\begin{array}{l}\text { Real Bank Private Credit } \\
\text { Growth }\end{array}$ & $\begin{array}{l}0.2585^{* *} \\
(2.42)\end{array}$ & $\begin{array}{c}0.2109^{* *} \\
(2.03)\end{array}$ & $\begin{array}{c}0.2487^{* *} \\
(2.21)\end{array}$ \\
\hline $\begin{array}{l}\text { Bank Loan / } \\
\text { Private Credit }\end{array}$ & & $\begin{array}{c}0.5299^{* * *} \\
(2.99)\end{array}$ & $\begin{array}{c}0.5806^{* * * *} \\
(3.11)\end{array}$ \\
\hline $\begin{array}{l}\text { Real Bank Capital } \\
\text { Growth }\end{array}$ & & & $\begin{array}{l}0.0256 \\
(-0.88)\end{array}$ \\
\hline Adjusted $\mathrm{R}^{2}$ & 0.41 & 0.45 & 0.45 \\
\hline DW & 2.25 & 2.22 & 2.19 \\
\hline
\end{tabular}

Notes: 1) ${ }^{* *}$ denotes the coefficient estimate is significant at $5 \%$ level, and ${ }^{* * *}$ denotes significant at $1 \%$ level (t-values are in the parenthesis).

2) Constant was included in all regressions but not reported to save space. 
$<$ Figure 1> The Ratio of Latent NPL out of Total Corporate Sector Loan

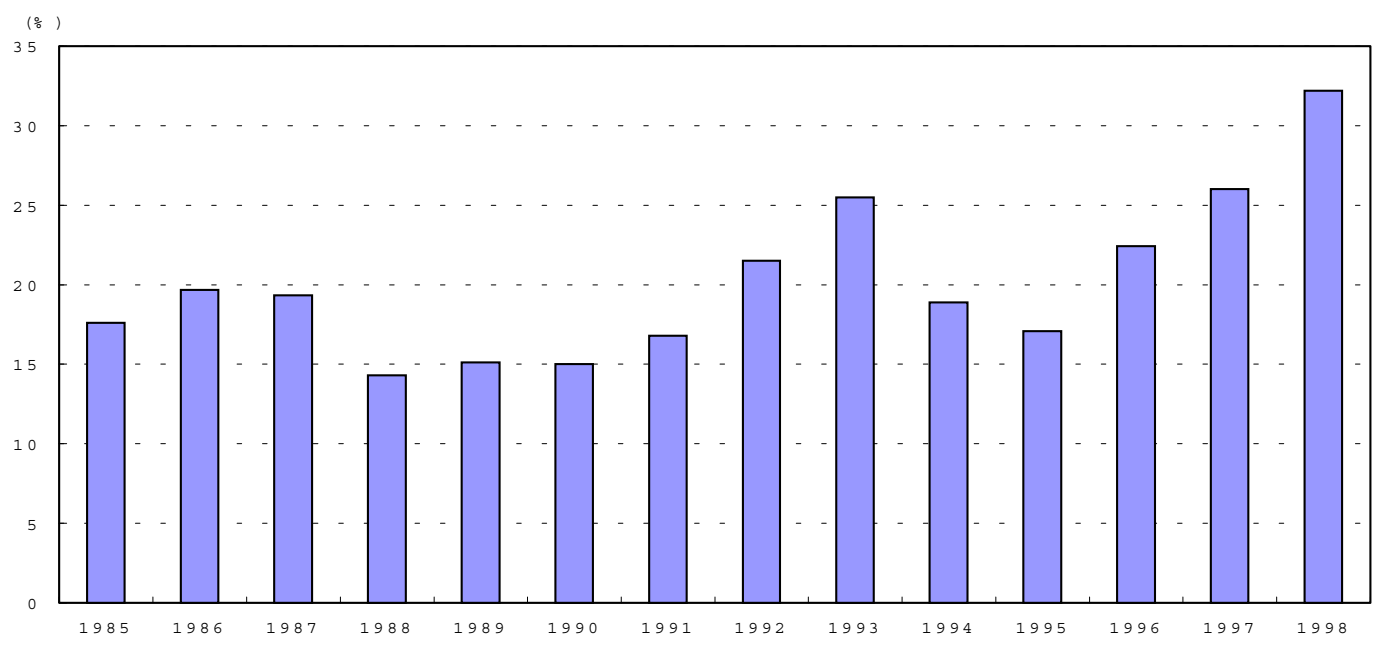

<Figure 2> Stock Market Performance of Commercial Banks Relative to Market

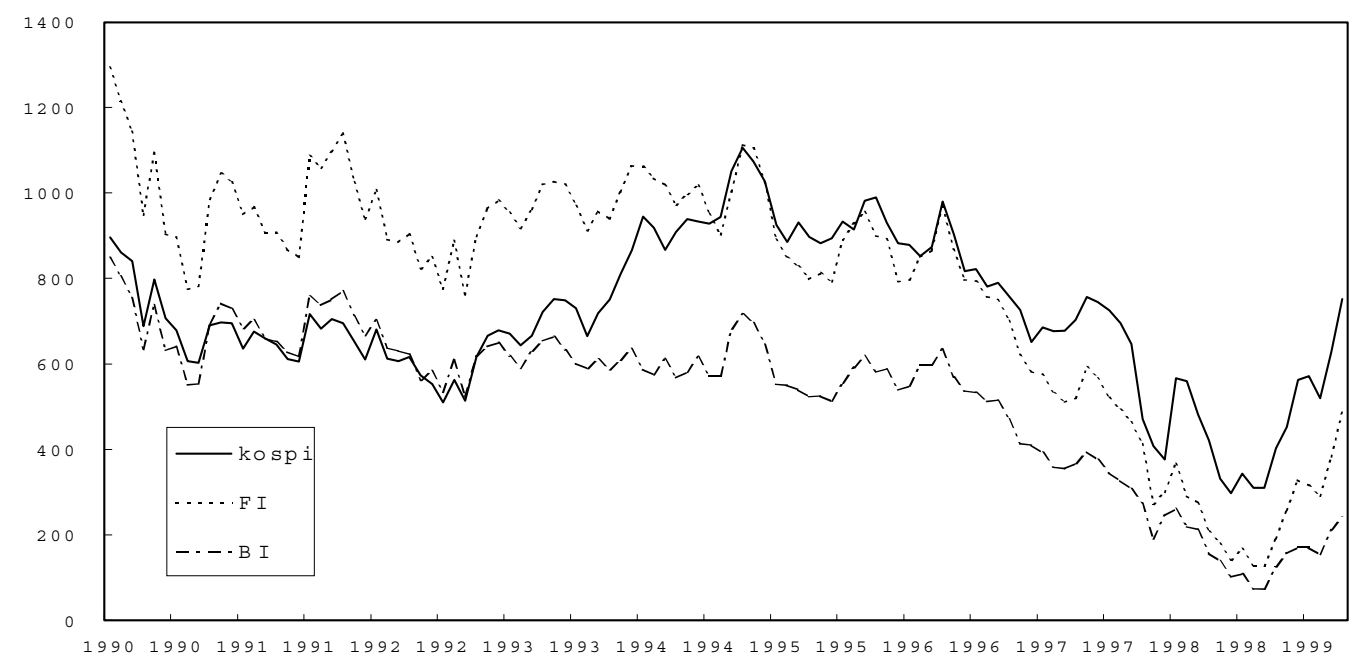


<Figure 3> External Liabilities of Financial Institutions

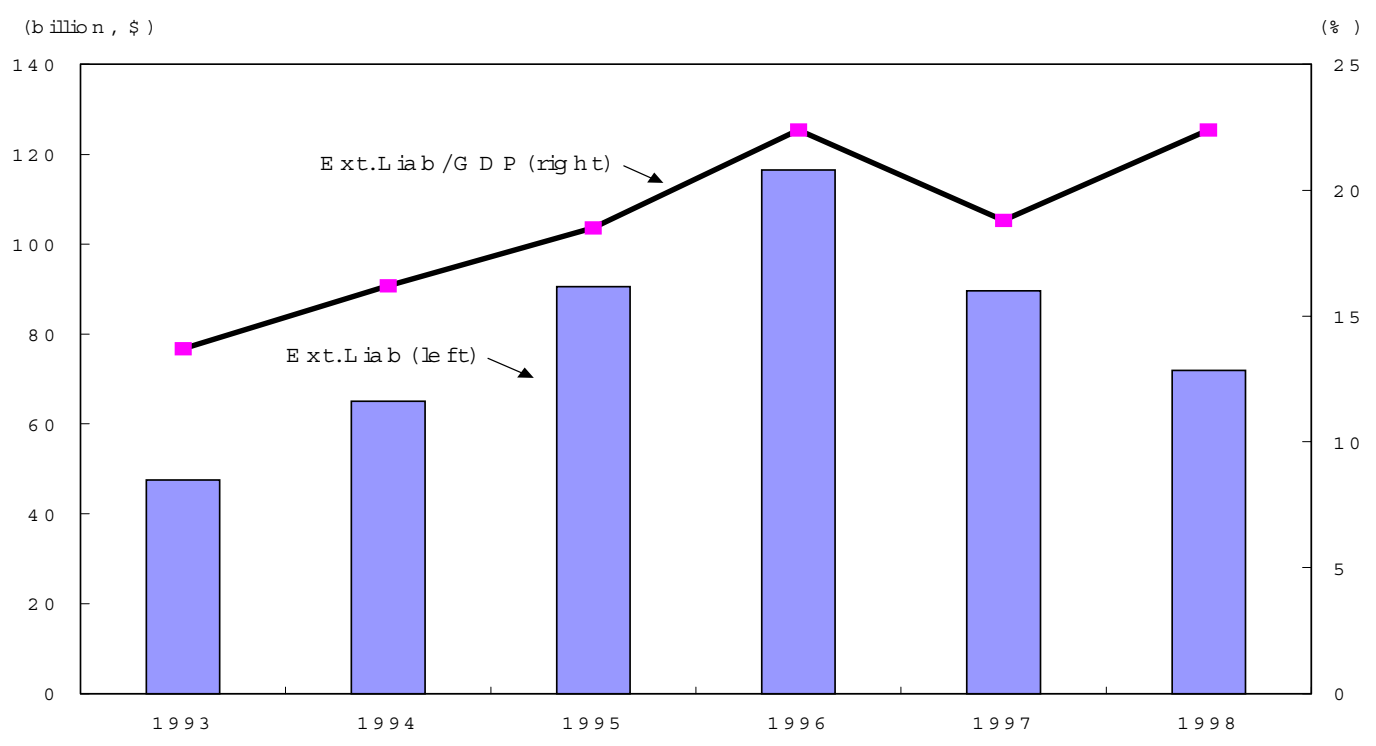

$<$ Figure 4> Corporate Debt to GDP and Debt-Equity Ratios

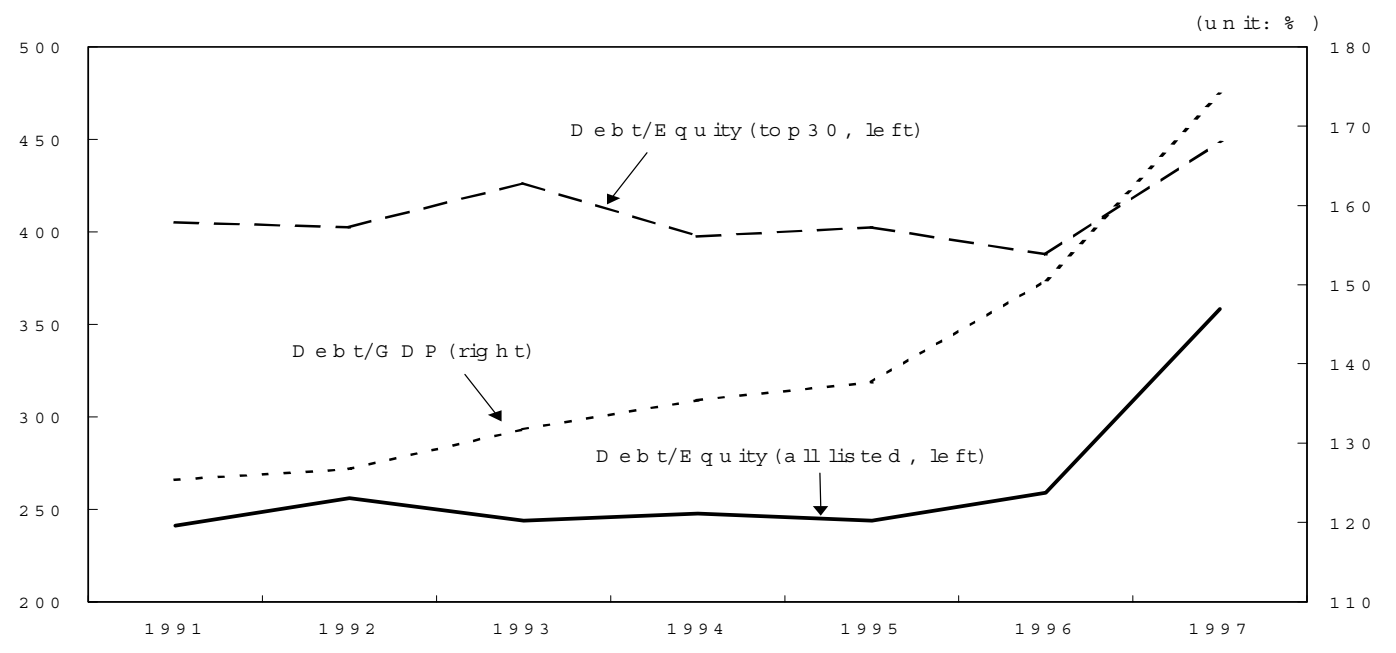


<Figure 5> The Incremental Capital-Output Ratio (ICOR)

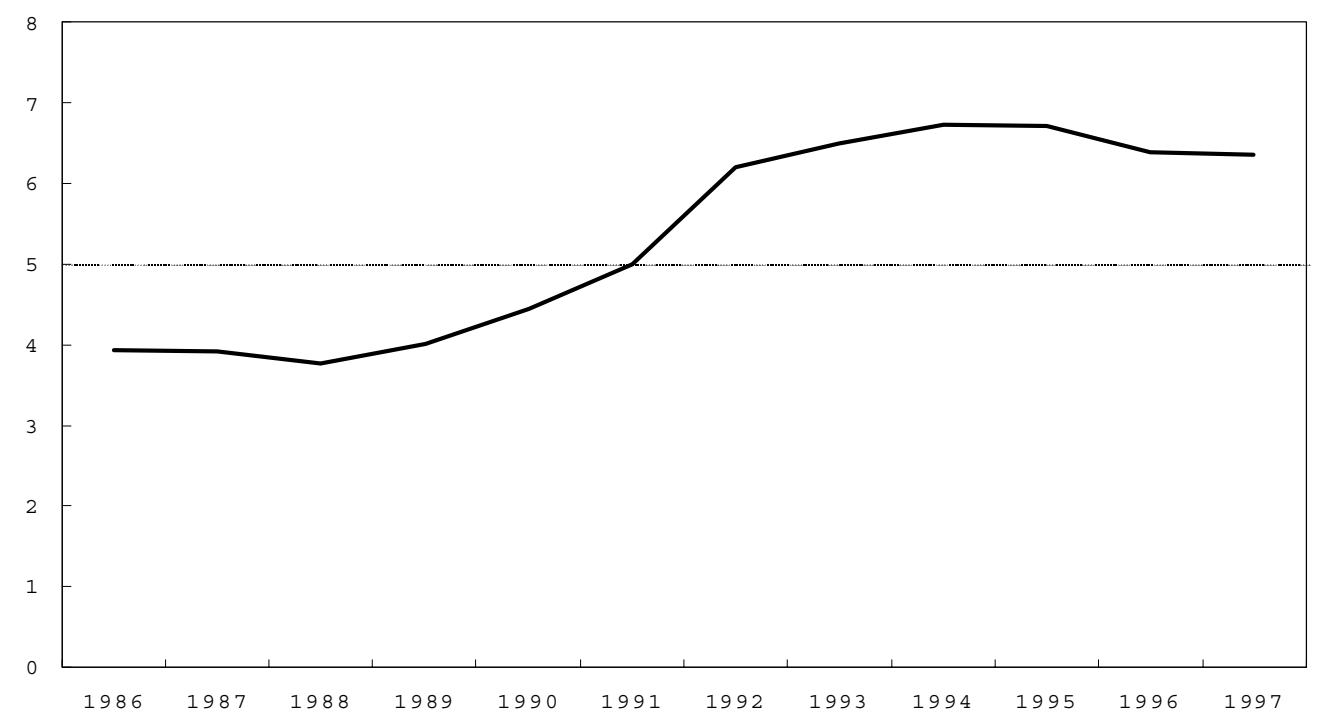


$<$ Figure 6> Sources of Corporate Financing
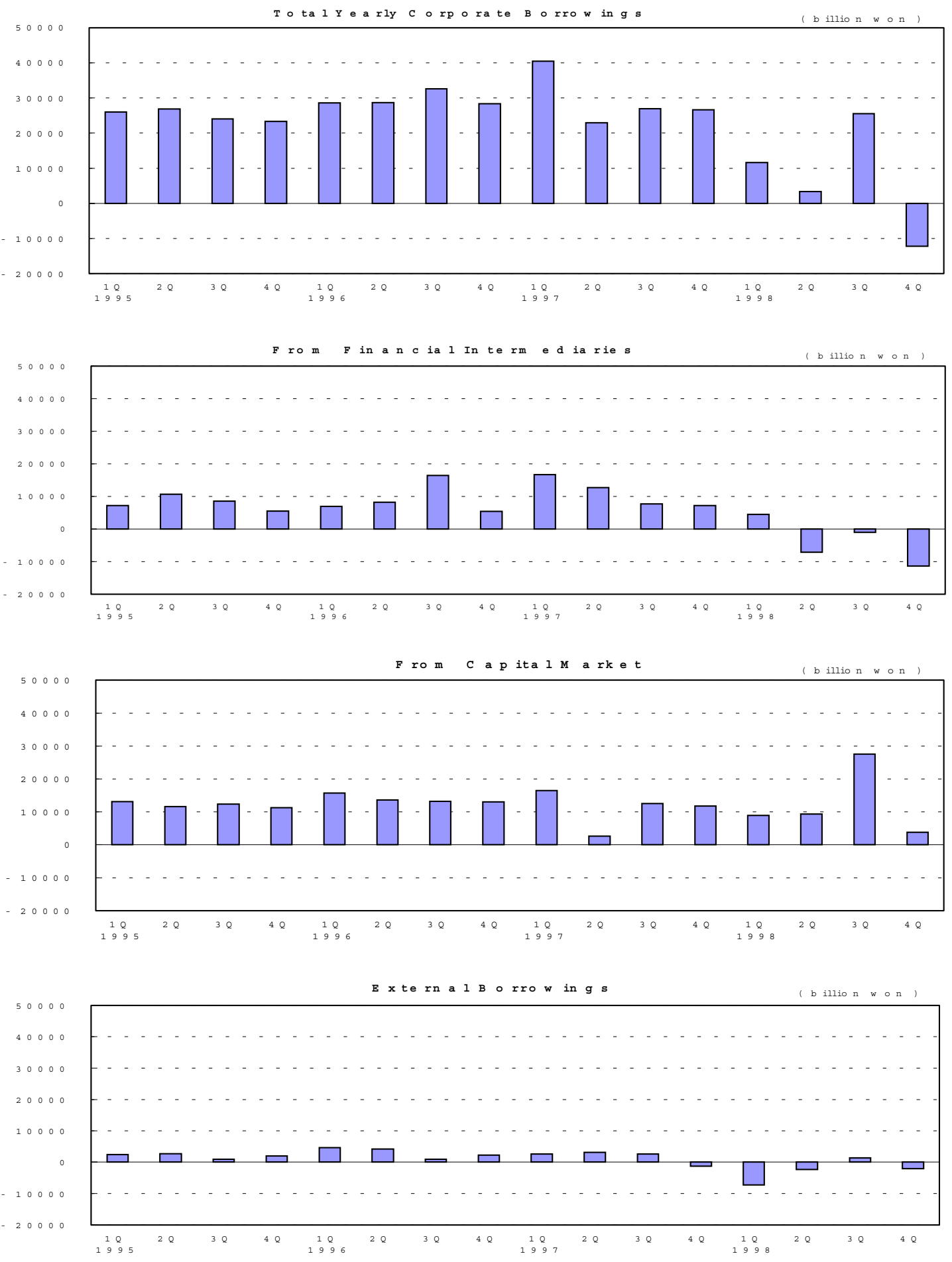
$<$ Figure 7> Domestic Credit of Financial Institutions

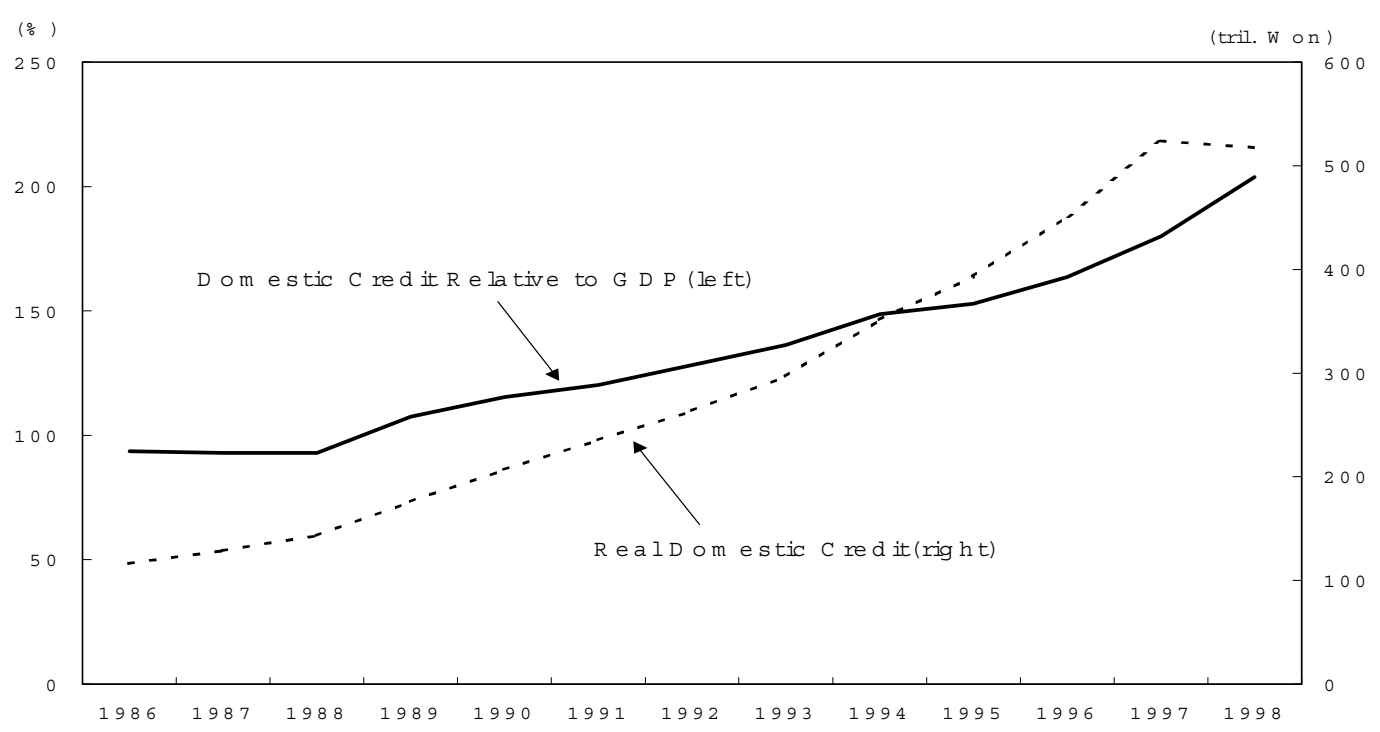

<Figure 8> The Terms of Trade

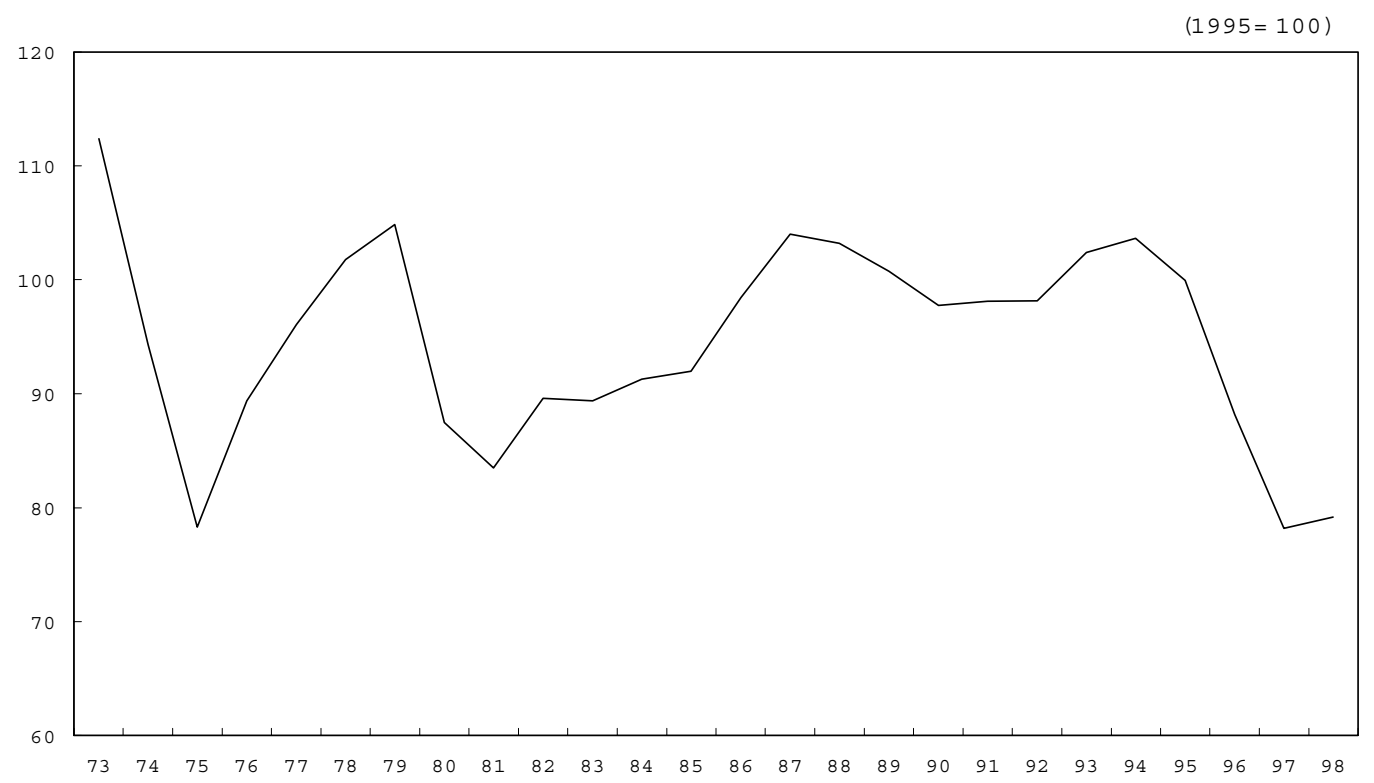


<Figure 9> Monetary Policy Response in the Crisis Episode

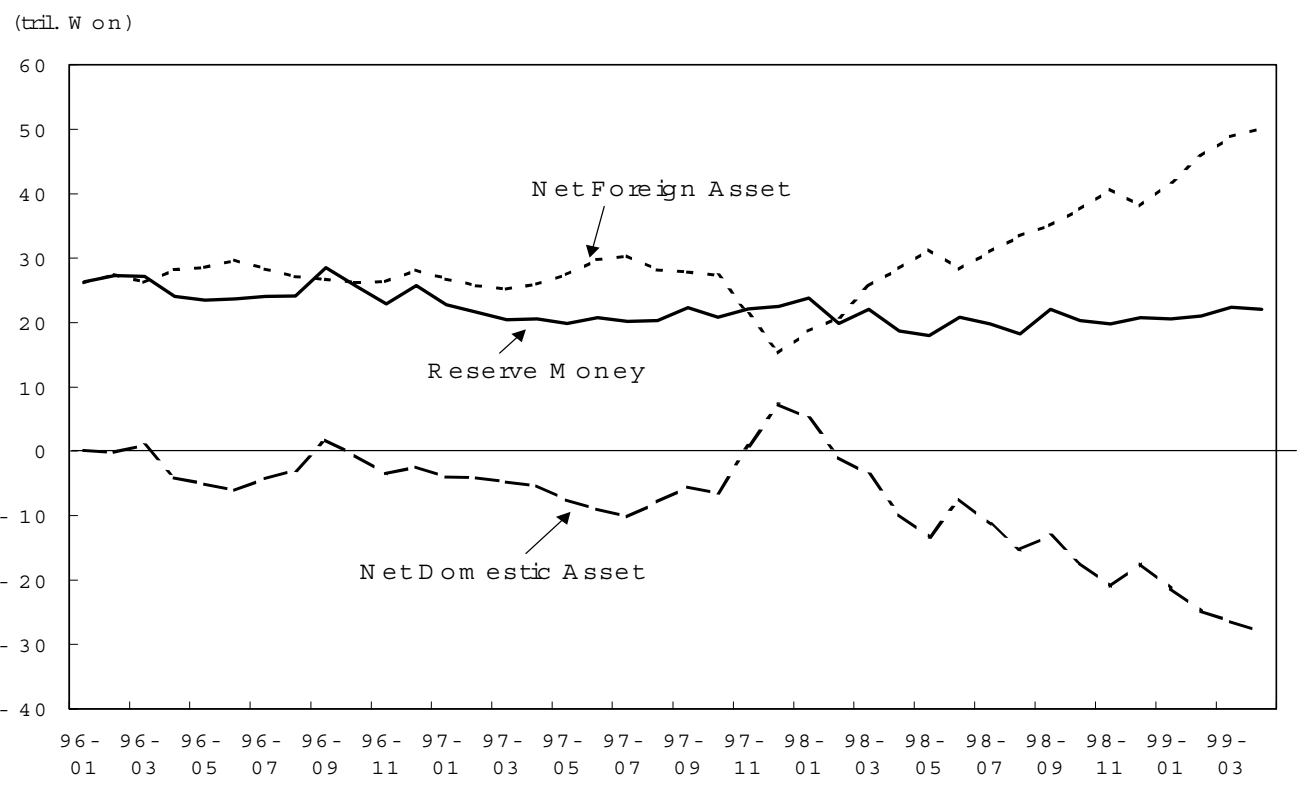

$<$ Figure 10> Spot Won/\$ Exchange Rates and NDF Futures Rate

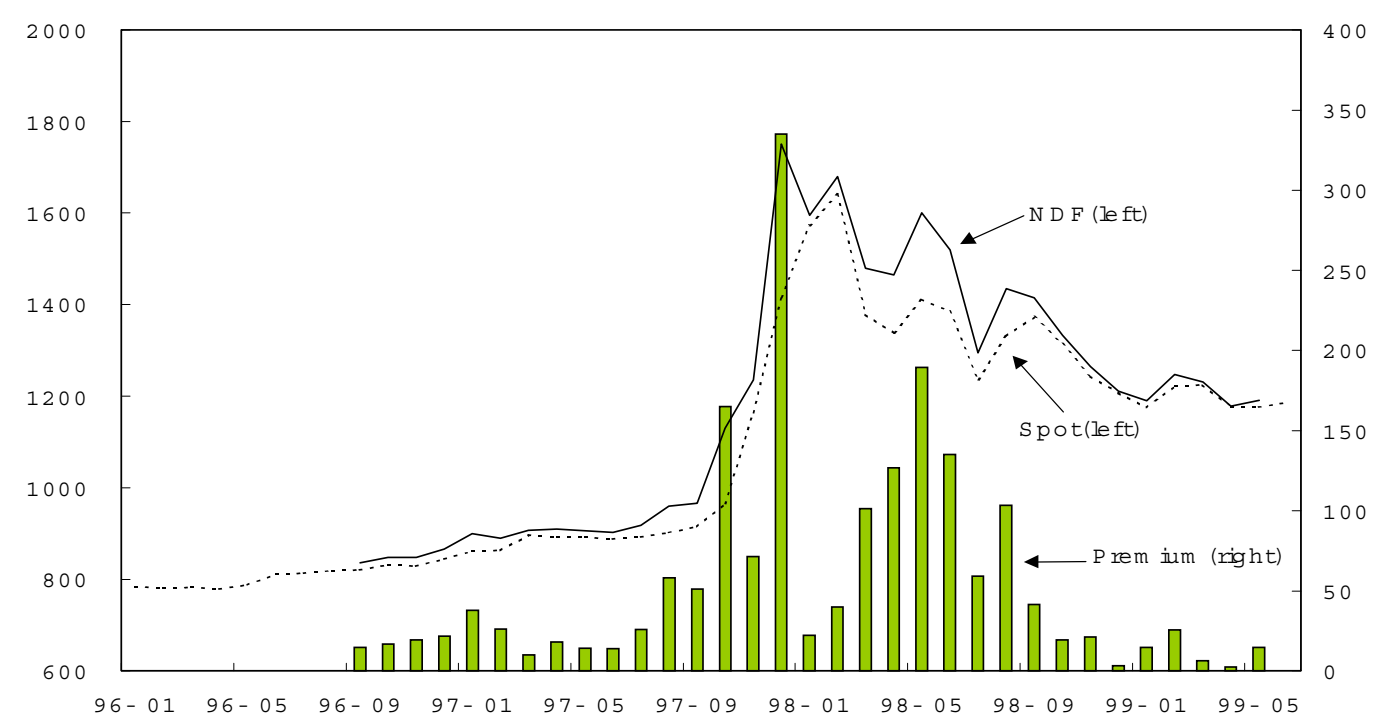

Note: 'Premium' denotes the difference between off-shore non-deliverable futures exchange rate quoted on 6-month contracts and domestic spot exchange rate quoted in on-shore foreign exchange market. 
$<$ Figure 11> Interest Rates and Dishonored Bill Ratio

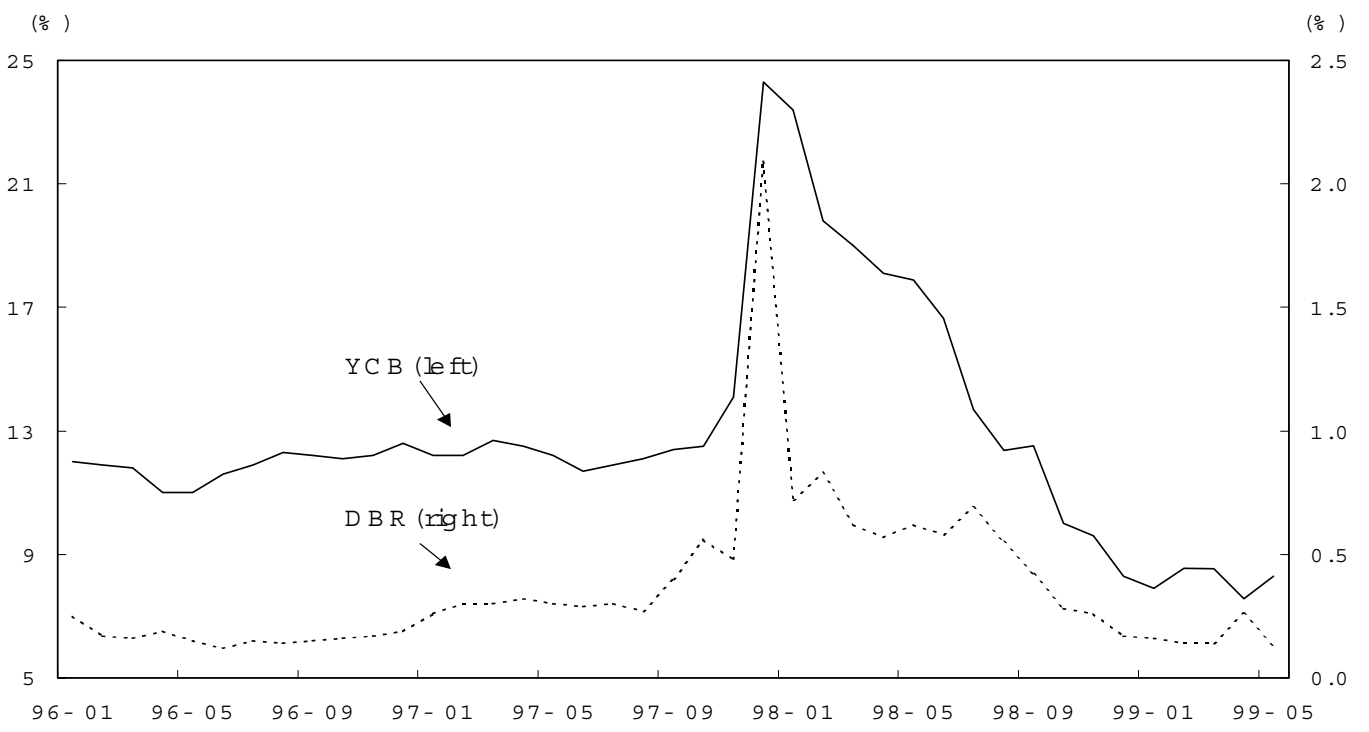

Note: 'YCB' denotes yields on the benchmark three year corporate bonds and 'DBR' denotes dishonored bill ratio.

<Figure 12> Growth Rates of Industrial Production (y-o-y growth rate)

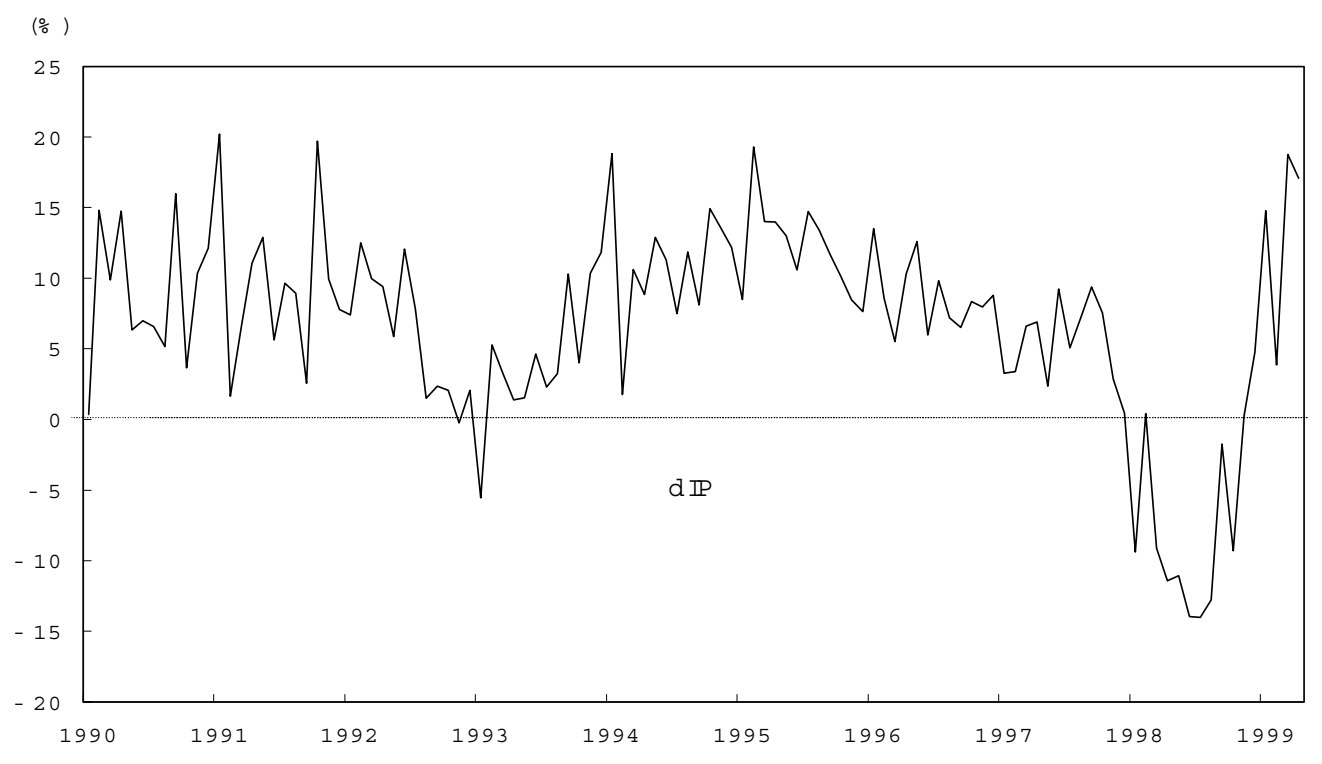


<Figure 13> Bank Loan Rate and Corporate Bond Yield Spread

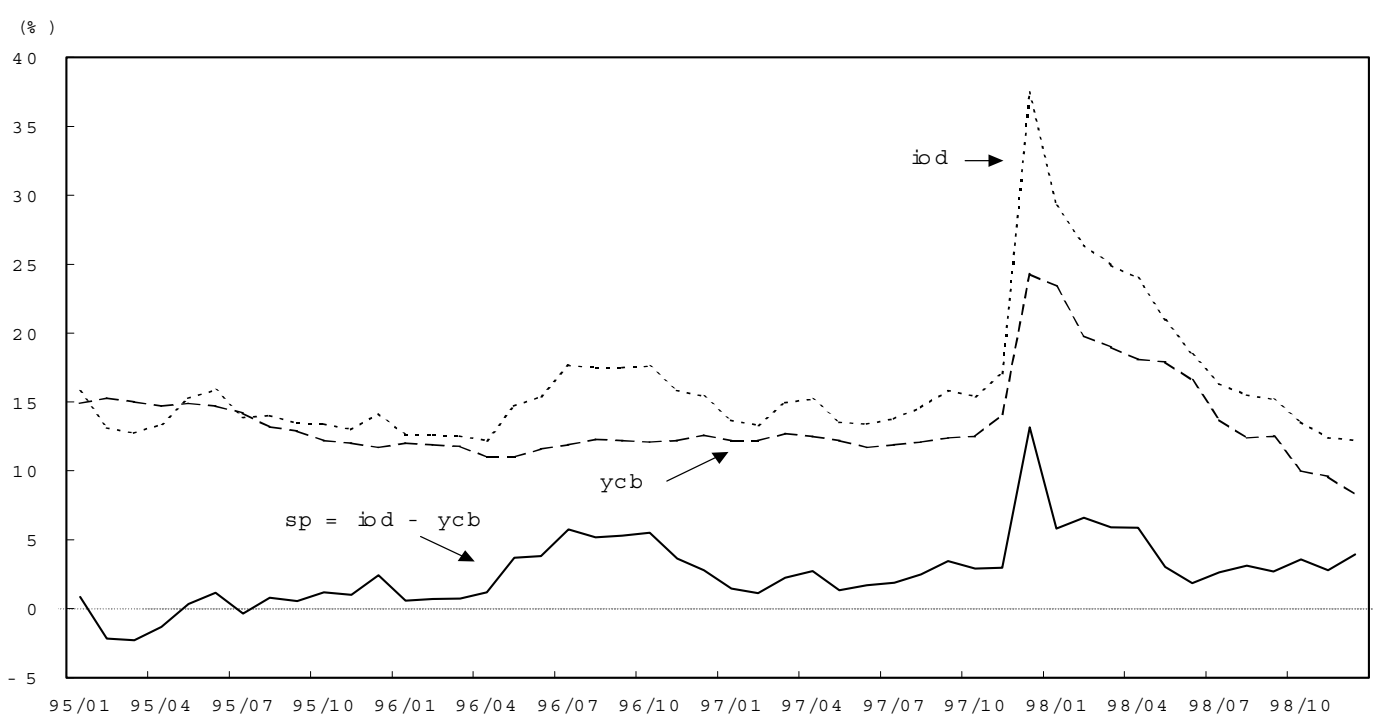

<Figure 14> Trend in the Corporate Financing Mix

(yearly borrowing from bank / yearly borrowing from bank, CP and corporate bond)

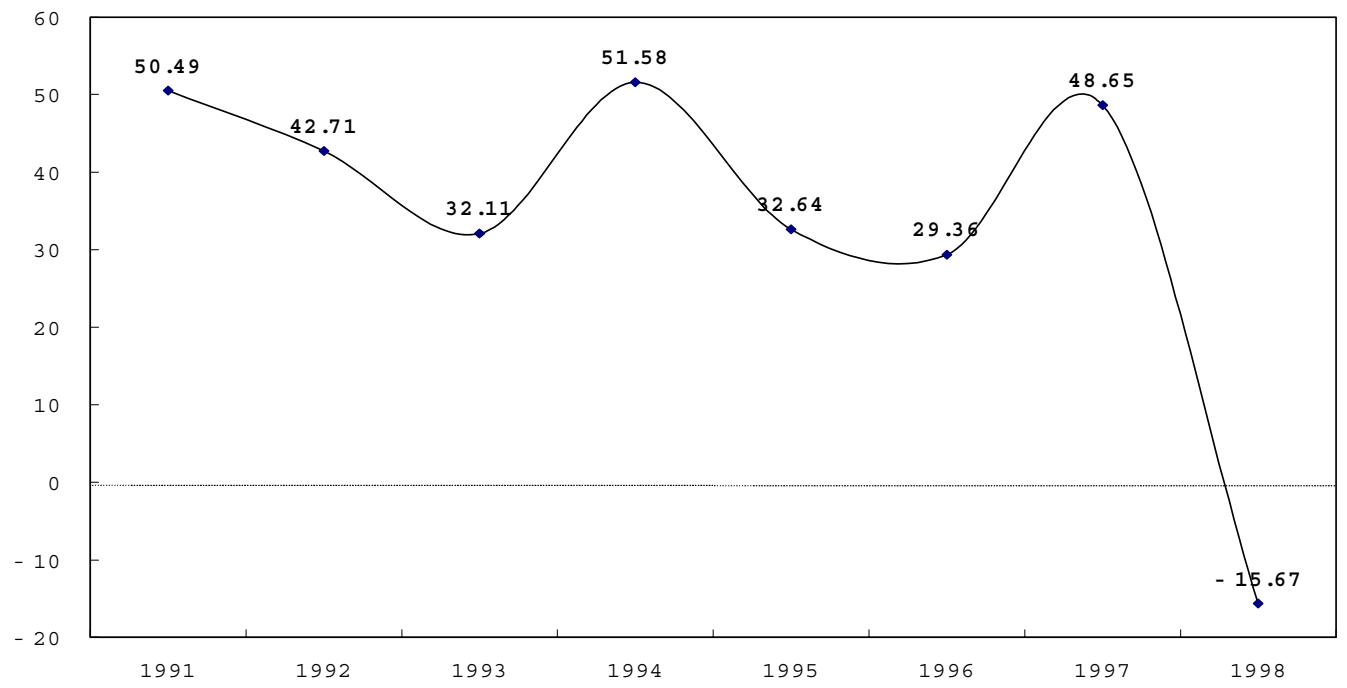


$<$ Figure 15> Growth Rates of Bank Private Credit and Loans (y-o-y growth rate)

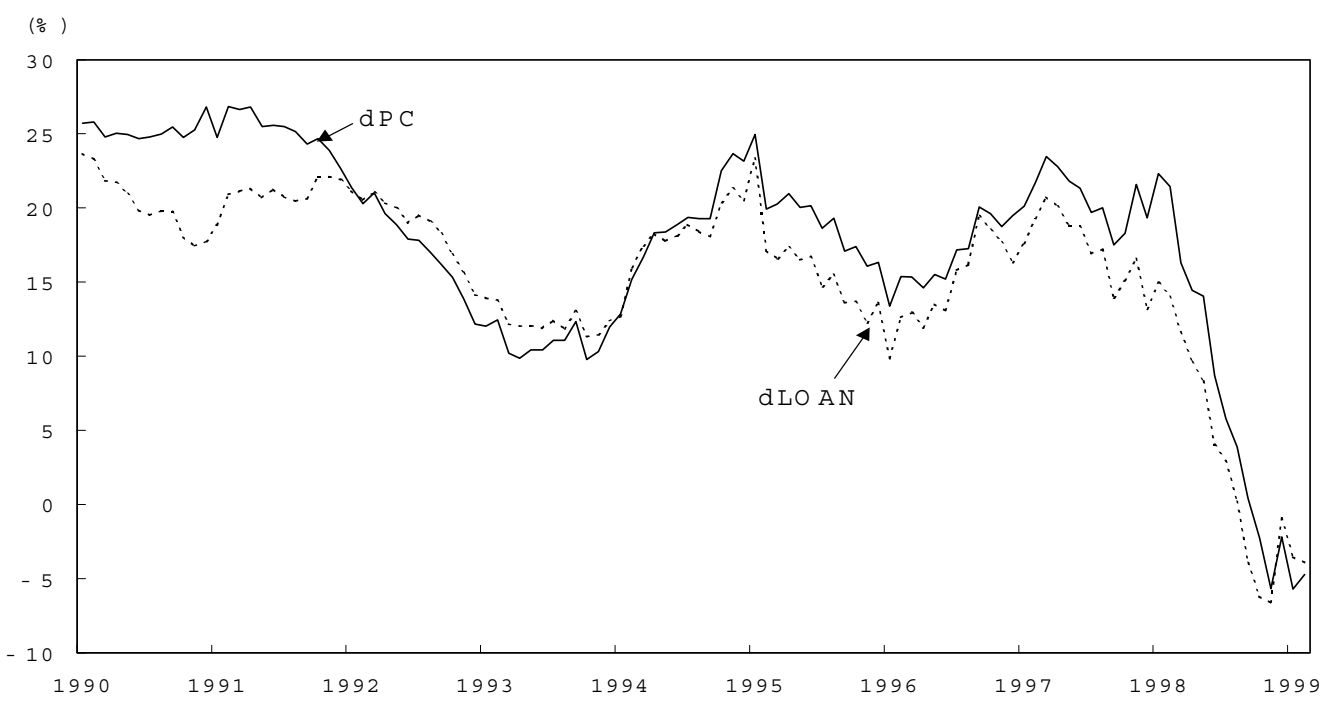

<Figure 16> Changes in Bank Asset Portfolio Composition

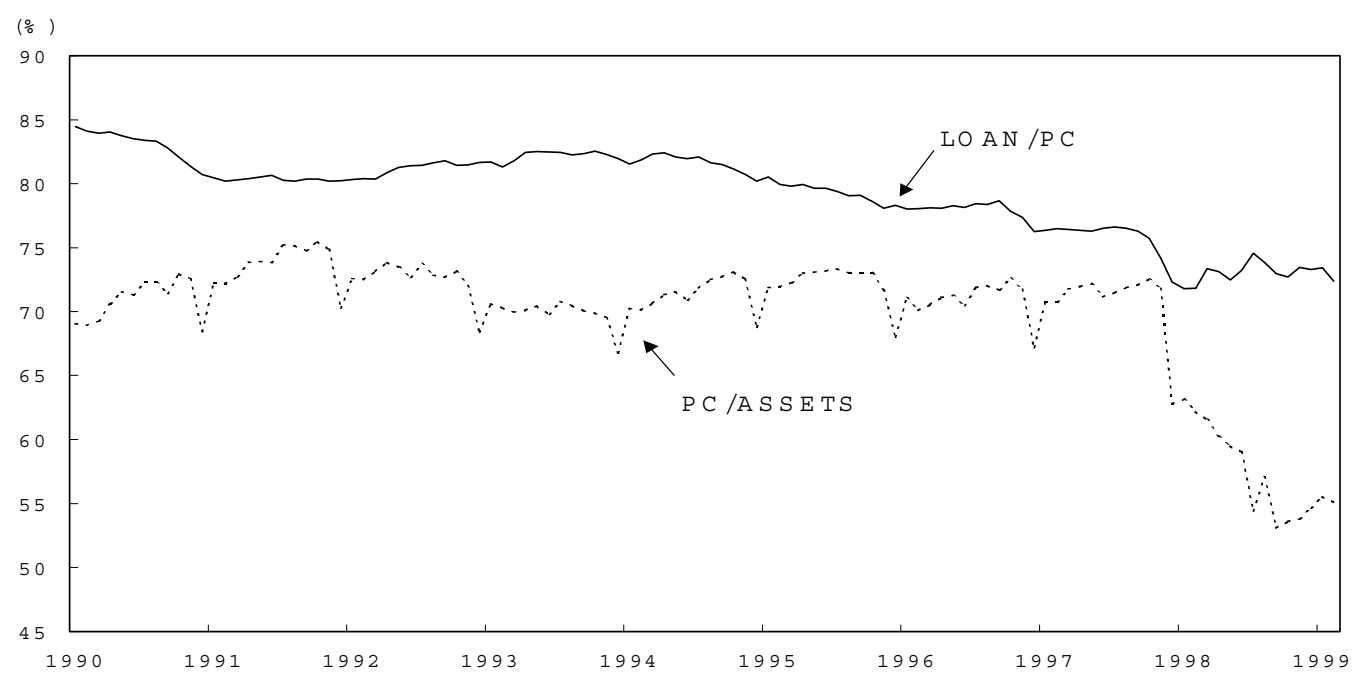

